\title{
an
}

The WiLliam DAVIDSON INSTITUTE AT THE UNIVERSITY OF MICHIGAN BUSINESS SCHOOL

\section{Real Exchange Rates in Transition Economies}

\author{
By: Boštjan Jazbec
}

William Davidson Working Paper Number 482

July 2002 


\title{
Real Exchange Rates in Transition Economies
}

\author{
Boštjan Jazbec ${ }^{*}$ \\ Faculty of Economics \\ University of Ljubljana \\ Slovenia
}

\begin{abstract}
Paper attempts to develop a model suitable for an analysis of the real exchange rate determination in transition economies. The main distinction from other approaches to the real exchange rate determination is an introduction of the pre-transition period which enables one to separately examine the role of adverse initial conditions and labor market reallocation between the tradable and non-tradable good sectors believed to characterize the extent of structural reforms in transition economies. Empirical findings seem to confirm that transition - when looking only at the real exchange rate behavior - is over once the progress in structural reforms does not affect the real exchange rate determination relative to other factors. Along the lines of research on growth prospects in transition economies, the effect of structural changes on the real exchange rate in more advanced transition economies has on average diminished in the fifth year of the transition process. The results for less advanced economies are in line with other studies on transition.
\end{abstract}

Keywords: transition economies, real exchange rate, fixed-effects model.

JEL: F31, F41, P22, P27

*bostjan.jazbec@uni-lj.si, Faculty of Economics, Kardeljeva pl. 17, 1000 Ljubljana, Slovenia.

I gratefully acknowledge Martin Raiser and Christof Rühl for sharing data. I have benefited from comments by Viatcheslav Vinogradov, Jan Svejnar, and Fabrizio Coricelli on earlier versions of this paper. All conclusions and remaining mistakes are of my own. 


\section{Introduction}

In spite of the importance that real exchange rates have attained in policy discussions, there are only few attempts to analyze empirically the forces behind real exchange rate behavior in transition economies. ${ }^{1}$ The works by Halpern and Wyplosz (1996), Krajnyak and Zettelmeyer (1998), and Richards and Tersman (1996) provide a noteworthy exception, which calls for further research in this direction. Transition has brought about important changes in production and productivity, and these changes should also influence the equilibrium exchange rate. The evidence on transition economies suggests that the experience of all transition economies with respect to productivity growth, trade liberalization, and capital inflows has not been the same. Thus, the equilibrium exchange rates may have appreciated or depreciated over time for these countries, even as their nominal rates seem to have moved toward their PPP rates (Brada, 1998). As already seen, the evidence on convergence of exchange rates toward PPP is hard to establish even for developed market economies, although one would in general accept that PPP holds in the long run. Moreover, the structural changes in transition economies should give warning to such convergence views since all transition economies have engaged in stabilization policies where macroeconomic equilibrium values were far from observable yet obtainable at the beginning of the transition process. The belief that a stable nominal exchange rate would provide an anchor not only to nominal variables but also to the real exchange rate has clearly turned out to be wrong in transition economies (Drabek and Brada, 1998).

Despite similar paths of the real exchange rates in transition economies, it is inevitable to ask whether the initially distorted economic environment in these economies have played any role in determining the real exchange rate behavior since the beginning of the transition process. Also, one should ask whether the real exchange rate path in transition economies was indeed determined only by supply side factors neatly introduced to the exchange rate story by the productivity differential approach. It seems that demand factors played an important role in determining the real exchange rates in transition economies. The arguments for this view can be grounded either in increase demand for non-tradables, which were previously not available on the market in transition economies, or by changed government consumption, which as a result of market reform now redirected its final destination to the market for non-tradables. This line of approach to the real exchange rate determination in transition economies would necessarily

${ }^{1}$ The research on the behavior of the real exchange rate in developing countries have started with works by Edwards (1989, 1994), Aghevli, Khan, and Montiel (1991), and economists primarily working at the World Bank or International Monetary Fund. The most important works from this group are presented in Hinkle and Montiel (1999). 
follow the conclusions from the empirical studies on growth in transition economies, which generally suggest that the initial conditions matter though they can be overpassed by the appropriate policy measures to correct the unfavorable starting points across transition economies. If this were the right approach, then one would be able to distinguish different factors that affect the real exchange rate in transition economies. The broad picture on the real exchange rate appreciation trend would, however, remain untouched. In so doing, one would be able to distinguish transition economies according to the scope of real appreciation, which remains for their economies before they start to lose their external competitiveness. In this sense, the approach would be similar to the one promoted by Krajnyak and Zettelmeyer (1998). However, the bias of using dollar wages as a measure of the real exchange rate index would be corrected by a more comparable measure of the real exchange rate, namely, the relative price of the tradables in terms of non-tradable goods.

The advantages of using the relative price of tradable goods over the external concept of the real exchange rate should also encourage its use in transition economies because the internal approach to the real exchange rate permits a straightforward analysis of the effects of productivity changes on the real exchange rate. First, if productivity rises faster in a country's tradable sector than in its non-tradable sector, then its relative price tradable goods measured in terms of non-tradables will appreciate. Second, if productivity also grows relatively faster in the home country's tradable sector than in the foreign country's, its relative price of tradables will also appreciate. And third, if the Law of One Price holds for the tradable goods, the external real exchange rate for tradable goods will be constant. In summing up the literature, it generally holds that there is some evidence for a productivity-based model of the real exchange rate. Recent studies on the behavior of the real exchange rate in transition economies support the argument for using the productivity approach to explain the trend appreciation of the real exchange rate in transition economies. There is a vast potential for gains in the productivity in transition economies both through more efficient use of existing resources and technologies and through upgrading technology. However, this approach should also take into account the initial conditions in transition economies at the beginning of reforms, as they vastly determined the macroeconomic policies and structural changes implied by the overall stance of the economies in those days. Decades of central planning have resulted in distorted structures of these economies. Industries had become overwhelming in the composition of output by the emphasis of central planners on material production, while services were largely neglected. The structure of the economy was reflected in distorted price levels as empirical studies on price development in transition economies indicate. Transition and the introduction of market-determined prices along the other market-enhanced reforms have brought about massive changes in output, employment, and last but not least, in relative prices. To analyze structural changes in transition economies, it is, 
therefore, useful to use the approaches that take into account the real changes in fundamentals rather than models with established patterns of developments in market economies. As such, the productivity approach to the real exchange rate determination serves as a natural candidate for the analysis of the real exchange rate in transition economies.

The aim of this paper is to develop a model for a real exchange rate determination in transition economies. A digression from a standard approach to the real exchange rate determination in transition economies is presented in Section 2. It is argued that the central plan determined relative prices and the labor market in such a way that it was inevitable for the real exchange rate to appreciate once the structural reforms in transition economies began. Section 3 incorporates the characteristics of the pre-transition period into a model of real exchange rate determination based on productivity approach to the real exchange rate. It is shown that productivity differential between labor productivity in the tradable and non-tradable sector, private demand for non-tradable goods, real government consumption, and structural reforms implemented to correct for distortions inherited from the pre-transition period of central planning, negatively affect the real exchange rate, and as such, contribute to the real exchange rate appreciation. Section 4 describes data and outlines the econometric approach used in the empirical part of this paper. Section 5 presents key results and conducts some specification tests. Empirical findings seem to confirm that transition - when looking only at the real exchange rate behavior - is over once the progress in structural reforms does not affect the real exchange rate determination relative to other factors. This conclusion is in stark contrast with Halpern and Wyplosz (1996) who conclude that the transition is complete when the real appreciation stops. Section 6 concludes. 


\section{William Davidson Institute Working Paper 482}

\section{Pre -Transition Period of Central Plan}

The characteristics of the transition economies are captured by the initial relative price discrepancy between the relative price of tradable goods in terms of non-tradables in transition economies relative to the relative price of tradables in market economies. The price discrepancy is believed to be caused by the preferences of the central plan for the tradable goods production over the production of nontradables. The rationale for the relative preference for the tradable production could be found in a selfsustained structure of the pre-transition economy and physical characteristics of the tradable sector output of the economy. If services are considered to be the main representative of the non-tradable good, then it clearly follows that the central plan was much easier forecasted and determined in terms of 'measurable' quantities of tradable production. The notion of tradables should not be taken literally. It is enough to think about tradable production in terms of physically measurable output, whose price is determined in the world market.

However, there is one crucial distinction made to the classical two-sector model concerning the relationship between the real exchange rate development and labor market adjustment. It is shown that in a transition economy, the labor market adjustment owing to structural changes in the economy may affect the real exchange rate determination. In so doing, the causality is reversed: the flow of labor from one sector to another is one of the indicators of structural reforms, and as such, the determinant of the real exchange rate in transition economies.

Consider now that the classical assumptions of perfect competition and labor mobility do not hold anymore. Instead, the markets are governed by central planners who have different preferences in the economy. Assume that central planners have marked preferences for the tradable goods sector production. They set production of tradables to be larger relative to the production of non-tradables regardless of the market demand conditions:

$$
\mathrm{Y}_{\mathrm{T}}=\eta \mathrm{Y}_{\mathrm{N}}, \quad \eta>1
$$

As in the previous case, the production functions in both sectors are the same and subject to decreasing returns to scale with respect to the sole labor input:

$$
\mathrm{Y}_{\mathrm{i}}=\mathrm{aL}_{\mathrm{i}}^{\alpha}
$$




\section{William Davidson Institute Working Paper 482}

where a denotes the technology, which is assumed to be the same in both sectors $\mathrm{i}=$ tradable and nontradable, respectively. Production coefficient $\alpha$ takes values between 0 and 1. Of course, assumption on the same technology parameters, a, in both sectors is a restrictive one. However, it does not change the analysis substantially. It just simplifies the algebra and does not alter the conclusions, which follow. The assumption on equal technologies in both sectors of the pre-transition economy will be relaxed in the next section. By combining equations (1) and (2), one obtains the following:

$$
\mathrm{aL}_{\mathrm{T}}^{\alpha}=\eta \mathrm{aL}_{\mathrm{N}}^{\alpha}
$$

It follows that the tradable sector consequently employs relatively more labor than the nontradable production:

$$
\mathrm{L}_{\mathrm{T}}=\eta^{1 / \alpha} \mathrm{L}_{\mathrm{N}}
$$

The bias in production, which follows from equation (1) and consequently in labor employment described in (4) was widely observed in formerly centralized economies. These economies were inclined to favor heavy industry and industrial production at the expense of private housing, consumer goods and services (see, among others, Melitz and Waysand, 1996). Taking into account equation (1), labor market equilibrium is governed by the assumption of full employment. After proper normalization, labor market equilibrium is as follows:

$$
\mathrm{L}_{\mathrm{T}}+\mathrm{L}_{\mathrm{N}}=1
$$

Equations (4) and (5) together define the number of workers employed in non-tradable production:

$$
\mathrm{L}_{\mathrm{N}}=\frac{1}{1+\eta^{1 / \alpha}}
$$




\section{William Davidson Institute Working Paper 482}

As long as $\eta>1$, which is true by assumption, the non-tradable sector employs less workers relative to the tradable goods sector. If state-owned firms in both sectors of the planned economy still follow the profit maximization objective, then they would employ labor up to the point where the marginal product of labor equals the real wage paid in that sector. Any other employment decision would not substantially alter the conclusions, which follow. Employment decisions in tradable and non-tradable sectors are, therefore, designed as the following:

$$
\begin{aligned}
\mathrm{W}_{\mathrm{N}} & =\mathrm{P}_{\mathrm{N}} \mathrm{MPL}^{\mathrm{N}}=\mathrm{P}_{\mathrm{N}} \alpha \mathrm{aL} \mathrm{N}^{\alpha-1} \\
\mathrm{~W}_{\mathrm{T}} & =\mathrm{P}_{\mathrm{T}} \mathrm{MPL}^{\mathrm{T}}=\mathrm{P}_{\mathrm{T}} \alpha \mathrm{aL}_{\mathrm{T}}^{\alpha-1}=\mathrm{P}_{\mathrm{T}} \alpha \mathrm{a} \eta^{(\alpha-1) / \alpha}{\mathrm{L}_{\mathrm{N}}}^{\alpha-1} \\
& \approx \mathrm{W}(\eta) .
\end{aligned}
$$

From equation (8), it follows that the higher the preferences are of central planners for tradable goods production, the lower is the nominal wage attained in that sector:

$$
\begin{aligned}
\frac{\partial \mathrm{W}_{\mathrm{T}}}{\partial \eta} & =(\alpha-1) \mathrm{P}_{\mathrm{T}} \mathrm{a} \eta^{-1 / \alpha} \mathrm{L}_{\mathrm{N}}{ }^{\alpha-1}<0 \\
& =\frac{\partial \mathrm{W}(\eta)}{\partial \eta}<0 .
\end{aligned}
$$

Therefore, there exists the level of tradable production for which the wages in both sectors are the same. Central planners control the volume of tradable production by altering the preferences $\eta$ in a way that $\eta \geq \eta_{0}>1$, where $\eta_{0}$ presents the preferences for tradable production in one of the cases where $\mathrm{W}_{\mathrm{T}}\left(\eta_{0}\right) \geq \mathrm{W}_{\mathrm{N}}$. The other analytically relevant case when $\mathrm{W}_{\mathrm{T}}\left(\eta_{0}\right)<\mathrm{W}_{\mathrm{N}}$ is shown below.

It follows that there exists such a case where $\eta>\eta_{0}$, which establishes $W_{T}(\eta)=W_{N}=W^{E}$, where the latter defines the equilibrium wage in the pre-transition period. In such an example the relative price of a tradable good in terms of non-tradables is determined from equations (7) and (8) as the following:

$$
\frac{\mathrm{P}_{\mathrm{T}} \alpha \mathrm{a} \eta^{(\alpha-1) / \alpha} \mathrm{L}_{\mathrm{N}}^{\alpha-1}}{\mathrm{P}_{\mathrm{N}} \alpha \mathrm{L}_{\mathrm{N}}{ }^{\alpha-1}}=\frac{\mathrm{W}_{\mathrm{T}}}{\mathrm{W}_{\mathrm{N}}}=1 .
$$




\section{William Davidson Institute Working Paper 482}

Therefore, the relative price of tradables in terms of non-tradables in the pre-transition period is greater than 1. If the measure of the real exchange rate is taken to be the relative price of tradables in terms of non-tradables, then one could say that the value of the domestic currency is overvalued:

$$
\frac{\mathrm{P}_{\mathrm{T}}}{\mathrm{P}_{\mathrm{N}}}=\eta^{(1-\alpha) / \alpha}>1
$$

or

$$
\mathrm{P}_{\mathrm{N}}=\eta^{(\alpha-1) / \alpha} \mathrm{P}_{\mathrm{T}}
$$

In order to determine the equilibrium real wage in the pre-transition period, the weighted average price index, $\mathrm{P}_{\mathrm{a}}$, is constructed as the following:

$$
\begin{aligned}
P_{a} & =\frac{P_{T} Y_{T}+P_{N} Y_{N}}{Y_{T}+Y_{N}}=\frac{P_{T} \eta Y_{N}+P_{N} Y_{N}}{\eta Y_{N}+Y_{T}}= \\
& =\frac{P_{T} \eta+P_{N}}{\eta+1}=\frac{P_{T} \eta+\eta^{(\alpha-1) / \alpha} P_{T}}{\eta+1}= \\
& =\frac{P_{T}\left(\eta+\eta^{(\alpha-1) / \alpha}\right)}{\eta+1} .
\end{aligned}
$$

The price of tradable goods is determined in the world market and considered to be given to the pre-transition economy. The average price in the economy is, therefore, a function of central planners' preference to the tradable goods production. The real equilibrium wage, $\omega^{\mathrm{E}}$, is given by the following:

$$
\omega^{\mathrm{E}}=\frac{\mathrm{W}^{\mathrm{E}}}{\mathrm{P}_{\mathrm{a}}}=\frac{\mathrm{W}_{\mathrm{T}}(\eta)}{\mathrm{P}_{\mathrm{a}}} \text {. }
$$

From (6), (8), and (13), the real equilibrium wage, $\omega^{\mathrm{E}}$, for the pre-transition period is determined by the productivity parameter, A, the production coefficient, $\alpha$, and preferences of central planners for the tradable goods production, $\eta$ : 


$$
\begin{aligned}
\omega^{\mathrm{E}}= & \frac{\mathrm{P}_{\mathrm{T}} \alpha \mathrm{a} \eta^{(\mathrm{a}-1) / \mathrm{a}} \mathrm{L}_{\mathrm{N}}{ }^{\mathrm{a}-1}}{\eta+\eta^{(\mathrm{a}-1) / \mathrm{a}}} \\
\eta+1 & \mathrm{P}_{\mathrm{T}} \frac{\alpha a \eta^{(\mathrm{a}-1) / \mathrm{a}}(\eta+1)}{\eta+\eta^{(\mathrm{a}-1) / \mathrm{a}} \frac{1}{1+\eta^{1 / ?}}} .
\end{aligned}
$$

The preferences of central planners, $\eta$, represent the non-market structure of the economy where the plan dominates over market forces. Since technology is given by the same production functions in both sectors of the economy, the real equilibrium wage can easily be defined solely as a function of the central plan and thus abstracted from market forces:

$$
\omega^{\mathrm{E}}=\omega(\eta)
$$

Consequently, the preferences of central planners stand as a proxy for the initial conditions in transition economies. The higher is the required volume of the tradable goods production, the greater is the initial price discrepancy between the relative tradable prices measured in terms of non-tradables in transition economies and market economies.

However, consider now the second case where the price of tradables in transition economies is not high enough relative to the level of non-tradable prices. In this case, nominal wages in the tradable sector would never reach the level of nominal wages in the non-tradable sector: $W_{T}(\eta)<W_{N}$. It follows that the central plan could never reach the targeted level of the tradable goods production, because workers would rather work in the non-tradable sector. It is assumed, however, that the central plan and the communist regime cannot fully determine where workers should work. Workers have some choice between the two sectors in the sense that they could choose where they would like to work. If the extent of the non-tradable sector is somehow limited, then the targeted level of the tradable goods production could be reached only if there exist wage subsidies to workers in the tradable sector paid by the central plan. The value of subsidy is determined by the difference between the 'equilibrium' nominal wage, $\mathrm{W}^{\mathrm{E}}$, as defined by equation (9) and the wage, $\mathrm{W}_{\mathrm{T}}^{0}$, defined as the following: 


$$
\mathrm{W}_{\mathrm{T}}^{0}=\mathrm{P}_{\mathrm{T}} \mathrm{MPL}^{\mathrm{T}}=\mathrm{P}_{\mathrm{T}} \alpha \mathrm{aL}_{\mathrm{T}}{ }^{\alpha-1}=\mathrm{P}_{\mathrm{T}} \alpha \mathrm{a} \eta_{0}{ }^{(\alpha-1) / \alpha} \mathrm{L}_{\mathrm{N}}{ }^{\alpha-1}, \quad \eta>\eta_{\mathrm{o}}>1
$$

where $\mathrm{W}_{\mathrm{T}}^{0}\left(\eta_{0}\right)<\mathrm{W}_{\mathrm{T}}(\eta)=\mathrm{W}_{\mathrm{N}}$.

Therefore, the wage subsidy, $\mathrm{S}$, is equal to:

$$
\mathrm{S}=\mathrm{W}^{\mathrm{E}}-\mathrm{W}_{\mathrm{T}}^{0}
$$

The wage in the tradable sector, $\mathrm{W}_{\mathrm{T}}$, is the wage actually paid in the tradable sector after subsidization:

$$
\mathrm{W}_{\mathrm{T}}=\mathrm{W}_{\mathrm{T}}^{0}+\mathrm{S} \text {. }
$$

How this subsidy is financed in the economy is not important for the analysis, which follows. However, it is relevant how the removal of the subsidy after the reforms are implemented affects the relative price of tradables in terms of non-tradable goods. To see this effect, note that the equilibrium in the labor market requires subsidized wages in the tradable sector to be equal to non-tradable nominal wages:

$$
\mathrm{W}_{\mathrm{T}}^{0}+\mathrm{S}=\mathrm{W}_{\mathrm{N}}
$$

By plugging in equations (7) and (17), we obtain:

$$
\mathrm{P}_{\mathrm{T}} \alpha \mathrm{a} \eta_{0}^{(\alpha-1) / \alpha} \mathrm{L}_{\mathrm{N}}^{\alpha-1}+\mathrm{S}=\mathrm{P}_{\mathrm{N}} \alpha \mathrm{aL}_{\mathrm{N}}{ }^{\alpha-1}
$$

from which the relative price of tradables in terms of non-tradables is determined as the following: 


$$
\frac{\mathrm{P}_{\mathrm{T}}}{\mathrm{P}_{\mathrm{N}}}=\eta_{0}{ }^{(1-\alpha) / \alpha}-\frac{\mathrm{S}}{\alpha a \eta_{0}^{\left({ }^{(\alpha-1) / \alpha} \mathrm{L}_{\mathrm{N}}{ }^{\alpha-1}\right.}}
$$

which is only the special case of equation (11) when wage subsidies in the tradable sector, S, are zero. For ratio $\mathrm{P}_{\mathrm{T}} / \mathrm{P}_{\mathrm{N}}>1$, the subsidy $\mathrm{S}$ should not exceed the wage paid in the non-tradable sector, $\alpha \mathrm{AL}_{\mathrm{N}}{ }^{\alpha-1}$. Additionally, it is assumed that the production coefficient, $\alpha$, is not very large. Nonetheless, equation (22) provides an explanation for an additional channel of the initial real exchange rate depreciation in transition economies at the beginning of the reforms ${ }^{2}$. If subsidies are removed, the ratio $\mathrm{P}_{\mathrm{T}} / \mathrm{P}_{\mathrm{N}}$ instantaneously increases by $\quad \mathrm{S} /\left(\alpha \mathrm{A} \eta_{0}{ }^{(\alpha-1) / \alpha} \mathrm{L}_{\mathrm{N}}{ }^{\alpha-1}\right)$. It is believed that this was the case in almost all transition economies (Halpern and Wyplosz, 1996). The removal of subsidies also initiates the inter-sectoral resource reallocation. Since the tradable sector cannot pay the wage equal to the wage determined in the nontradables sector, workers previously employed in the tradable sector seek employment in the production of non-tradables. It is believed that the initial sharp depreciation and surplus capacity - a relatively large number of resources employed in industrial production, which is traditionally accounted for a tradable sector - early in the transition process provided an environment for relatively smooth process of recovery without engaging in fundamental restructuring. However, the progress in reforms and rapid appreciation of the real exchange rate was mainly caused by the reform efforts and structural changes in the economies that have begun to deflate the 'cushions' for enterprises at the beginning of transition (EBRD Transition Report, 1998). One of the structural parameters indicating the extent of reform in transition could therefore be taken to be the ratio of labor employed in the non-tradable sector relative to labor employed in tradable goods production.

Equations (11) and (22) show that the price differential between tradables and non-tradables could be explained by the non-market structure of the pre-transition economy mainly determined by the choice of the central plan. Alternatively, the price differential between tradables and non-tradables can be explained solely by removing the assumption of equal technologies employed in the tradable and nontradable sectors, respectively. This approach is well documented in literature, with seminal contributions including the work of Balassa (1964) and Samuelson (1964), and lately followed by Bhagwati (1984). Their points are illustrated in the following simple framework. Assume that prices of tradables are determined in the world market and therefore equalized across countries. Prices of non-tradables are assumed to be determined domestically based on the domestic wage and productivity levels. To the extent that productivity in the two sectors within the country grows at different rates, it is likely that there will be offsetting movements in the relative price of tradables in terms of non-tradables. If the trend growth of

${ }^{2}$ The other channels of initial real depreciations are obviously price liberalization and devaluation of the nominal exchange rate. 


\section{William Davidson Institute Working Paper 482}

productivity in the tradable goods sector exceeds that of the non-tradable goods sector, there will be a tendency for the relative price of tradables to decline over time.

To explain the price differential, assume that there is an economy-wide wage that is equal to the marginal product of labor in each sector. To the extent that there are differences in productivity across countries, wages will differ as well. In less developed countries, productivity is generally lower than in more developed countries. While this applies to both sectors of the economy, there is evidence that the productivity gap is larger for tradables than it is for non-tradables. Also, the scope for productivity gain is more limited in non-tradables than in tradables. Because of this, the price of non-tradables will typically be lower in less developed countries than in industrial countries. Since the overall price level is a weighted average of the price levels of tradable and non-tradable goods, the general price level will be lower in less developed countries, with the difference being a function of the proportion of goods that are non-tradable, and the price differential for non-tradables (Richards and Tersman, 1996). Coorey, Mecagni, and Offerdal (1996) provide evidence for the difference between overall price level for selected transition economies and the overall Austrian price level in 1993 and conclude that the differences between price levels range between 65 to 90 percent in favor of Austrian prices. For some non-tradables, this difference is even wider. In Moldova, for example, the price of communication services reached only 4 percent of the equivalent Austrian price in 1993. Richards and Tersman (1996) provide evidence for lower prices in the Baltic countries when comparing them to countries with similar income levels. When comparing the Baltics with their neighbor, Sweden, they conclude that, for example, in Latvia in early 1994, the general level of consumer prices was no more than 35 percent of the Swedish level, or no more than 40 percent of the U.S. level. They point out, however, that part of this estimated differential may be due to quality differences. Nonetheless, the difference is substantial and requires an explanation that may be grounded in subsidies to the tradable sector, which has mainly consisted of industry and manufacturing in the previously centralized economies. 


\section{William Davidson Institute Working Paper 482}

\section{Transition Period $^{3}$}

The first phase of the transition is characterized by the collapse of the central plan and the regime that has governed it. The key aspects and achievement of this period are the liberalization of prices and the beginning of the privatization of the economy. Most new enterprises arise in the non-tradable sector, which do not require large capital goods. Also, the entrepreneurial spirit is higher in the non-tradable sector since the central plan did not provide many of the services usually presented on the market in a developed economy. The competition strengthens in both sectors either because of the new firms or the restructured old ones. The privatization process is assumed to take place instantaneously, which implies that firms cannot be distinguished by their history. Firms in both sectors of the economy pursue the profit maximization motive. Workers in both sectors of the economy are organized in the centralized trade union, which takes care of the employment, and real wage objectives. Most of the first phase of transition is still determined by unfavorable initial conditions inherited from the old structure of the economy. These conditions are mainly encompassed by the relatively large share of workers employed in the traditionally industrial sector of the economy and price discrepancy between tradable and non-tradable price levels comparable to market economies.

Aggregate labor demand is the sum of the demand for labor in the tradable, $\mathrm{L}_{\mathrm{T}}$, and non-tradable goods sectors, $\mathrm{L}_{\mathrm{N}}$ :

$$
\begin{aligned}
\mathrm{L}^{\mathrm{d}} & =\mathrm{L}_{\mathrm{N}}+\mathrm{L}_{\mathrm{T}}= \\
& =\frac{\theta}{1-\theta} \frac{\mathrm{a}_{\mathrm{T}} \mathrm{L}_{\mathrm{T}}^{\alpha}}{\mathrm{W}}+\frac{\mathrm{G}}{\mathrm{a}_{\mathrm{N}}}+\left(\frac{\alpha \mathrm{P}_{\mathrm{T}} \mathrm{a}_{\mathrm{T}}}{\mathrm{W}}\right)^{1 /(1-\alpha)},
\end{aligned}
$$

where $\theta$ denotes the share of non-tradables, $\mathrm{C}_{\mathrm{N}}$, in private consumption; $\mathrm{a}_{\mathrm{T}}$ and $\mathrm{a}_{\mathrm{N}}$ are technology parameters specific to the production of tradable and non-tradable goods respectively; $\mathrm{W}$ represents nominal wage; and $\mathrm{G}$ is government consumption of non-tradables.

Clearly, labor demand is highly non-linear in nominal wages. The latter are defined as the following:

\footnotetext{
${ }^{3}$ The model presented in this section draws heavily on De Gregorio, Giovannini, and Krueger (1993). All derivations and explanations are left to the original source.
} 


\section{William Davidson Institute Working Paper 482}

$$
\begin{aligned}
\mathrm{W} & =\omega \mathrm{P}_{\mathrm{T}}^{1-\theta} \mathrm{P}_{\mathrm{N}}^{\theta} \\
& =\omega \mathrm{P}_{\mathrm{T}}^{1-\theta}\left(\frac{\Phi}{\Phi-1} \frac{\mathrm{W}}{\mathrm{a}_{\mathrm{N}}}\right)^{\theta} .
\end{aligned}
$$

Solving equation (24) for $\mathrm{W}$ gives us the following expression for nominal wages in function of real wage, price of tradable goods, and productivity parameter in production of non-tradables:

$$
\mathrm{W}=\omega^{1 /(1-\theta)} \mathrm{P}_{\mathrm{T}}\left(\frac{\Phi}{\Phi-1} \frac{1}{\mathrm{a}_{\mathrm{N}}}\right)^{\theta /(1-\theta)}
$$

When equation (25) is plugged into the labor demand function (23), one can establish the following:

$$
\begin{gathered}
\mathrm{L}^{\mathrm{d}}=\mathrm{L}\left(\omega, \mathrm{a}_{\mathrm{T}}, \mathrm{a}_{\mathrm{N}}, \mathrm{G}\right) \\
-+++
\end{gathered}
$$

Centralized trade union minimizes its quadratic objective function with respect to real wages:

$$
\min \left(\left(\mathrm{L}-\mathrm{L}^{*}\right)^{2}+\sigma\left(\omega-\omega^{*}\right)^{2}\right)
$$

subject to

$$
\mathrm{L}=\mathrm{L}^{\mathrm{d}}(\omega)
$$

Targeted real wages are assumed to be proportional to the pre-transition real equilibrium wage rate presented by equation (16). The targeted real wage for the union is, therefore, given by:

$$
\omega^{*}=\beta \omega^{\mathrm{E}}(\eta)
$$




\section{William Davidson Institute Working Paper 482}

Real wages dwindled at the beginning of reforms in almost all transition economies. The initial fall was quickly absorbed, and real wages started to increase thereafter. Halpern and Wyplosz (1996) and Krajnyak and Zettelmeyer (1998) provide evidence on real wage behavior measured in U.S. dollars. In terms of equation (29), the coefficient on pre-transition equilibrium real wages should, therefore, be positive, indicating the union's objective to raise the transition real wages at least to the levels experienced before the beginning of transition. The union's objective is relatively easy to comprehend once the political climate in a transition economy is seriously reconsidered (Aslund, Boone, and Johnson, 1996; Aizenman and Isard, 1996).

The solution to the optimization problem once equations (28) and (29) are plugged into the union's objective function is given by the following expression for the real wage:

$$
\omega=\frac{1}{\varepsilon^{2}+\sigma}\left[\sigma \beta \omega^{\mathrm{E}}(\eta)+\varepsilon\left(\mathrm{L}_{0}-\mathrm{L}^{*}\right)\right]
$$

The real wage is an increasing function of the targeted real wage determined by pre-transition levels, and positive shocks to the demand for labor determined by productivity parameters in both sectors of the economy and government consumption. The more distorted is the pre-transition equilibrium wage (the higher is the equilibrium wage determined by the central plan's objective to produce more of the industrial good relative to services), the higher is the pressure of the union to negotiate for higher wages once the transition starts. In order to see the mechanics of real wage determination at work, equation (30) is plugged back into the nominal wage equation (24), taking into account the conclusions that follow from the labor demand equation (26). In so doing, it is established that the nominal wage is an increasing function of the real wage determined by the pre-transition structural parameter, $\eta$, which takes into account a distorted measure of the transition economy, productivity parameters, and government consumption. The nominal wage is, therefore, determined as the following:

$$
\mathrm{W}=\mathrm{W}\left(\beta \omega(\eta), \mathrm{a}_{\mathrm{T}}, \mathrm{a}_{\mathrm{N}}, \mathrm{G}\right) .
$$

All variables enter the nominal wage equation with positive signs as expected. The only indeterminacy may arise from the sign of $\mathrm{a}_{\mathrm{N}}$, which can take either a positive or negative value. However, it is assumed that an increase in the non-tradable sector productivity in transition economies increases demand for labor to satisfy private sector demand in the tradable and non-tradable sectors (this follows from equation (26)) for less than an increase in the tradable sector productivity. The nominal wage 


\section{William Davidson Institute Working Paper 482}

equation is one of the most important equations in this framework since the real economy parameters enter the real exchange rate measure via the nominal wage equation. This link is established when equation (31) is plugged into an expression for the relative price of tradables in terms of non-tradable goods. It is assumed that the price of tradables is determined in the world market and, therefore, exogenously given to a transition economy. For this reason, the price of tradables could be normalized to 1 in order to provide the following expression for the real exchange rate measure:

$$
\frac{1}{\mathrm{P}_{\mathrm{N}}}=\frac{\Phi-1}{\Phi}\left(\frac{\mathrm{a}_{\mathrm{N}}}{\mathrm{W}\left(\beta \omega(\eta), \mathrm{a}_{\mathrm{T}}, \mathrm{a}_{\mathrm{N}}, \mathrm{G}\right)}\right)
$$

The real exchange rate measured as the relative price of tradables in terms of non-tradable goods, therefore, negatively depends on the productivity differential, the share of non-tradable consumption in total private consumption, and real government consumption. The parameter that measures the extent of structural misalignment inherited from the central plan, $\eta$, enters the real exchange rate equation with a positive sign. The regression equation used in the next section is presented as the following:

$$
\log \left(\mathrm{P}_{\mathrm{T}} / \mathrm{P}_{\mathrm{N}}\right)_{\mathrm{i}, \mathrm{t}}=\alpha_{\mathrm{oi}}-\alpha_{1} \log \left(\mathrm{a}_{\mathrm{T}}-\mathrm{a}_{\mathrm{N}}\right)_{\mathrm{i}, \mathrm{t}}-\alpha_{2} \text { share }_{\mathrm{i}, \mathrm{t}}-\alpha_{3} \text { govreal }_{\mathrm{i}, \mathrm{t}}+\alpha_{4} \operatorname{lab}_{\mathrm{i}, \mathrm{t}}+\varepsilon_{\mathrm{i}, \mathrm{t}}
$$

where $\left(\mathrm{P}_{\mathrm{T}} / \mathrm{P}_{\mathrm{N}}\right)_{\mathrm{i}, \text { t, }}$ is the relative price of tradables in terms of non-tradable goods; $\left(\mathrm{a}_{\mathrm{T}}-\mathrm{a}_{\mathrm{N}}\right)_{\mathrm{i}, \mathrm{t}}$ is the productivity differential between tradable and non-tradable goods production and is measured in terms of labor productivity in both sectors; share $_{i, t}$ represents the share of non-tradable consumption in total private consumption; govreal $\mathrm{i}_{\mathrm{i}, \mathrm{i}}$ is the share of government consumption in GDP measured in constant prices; and $\mathrm{lab}_{\mathrm{i}, \mathrm{t}}$ represents the structural misalignment variable. It is proxied by the ratio between labor employed in the tradable sector versus labor employed in the non-tradable sector. This formulation follows from equation (4). The sign of all coefficients is negative except the sign on the structural variable, which enters the equation with a positive sign. This constitutes the positive correlation between the real exchange rate and the labor employed in the tradable sector relative to the non-tradable sector. For this reason, the structural variable proxied by the labor ratio represents the parameter that measures the rigidity of the labor market to the structural changes in the economy. As for the rest of the story, this rigidity is assumed to be exogenously determined in the economy, and thus, independent from all other right-hand side variables in equation (33). This is a rather stringent assumption on the structure of a transition economy, and its validity can be seriously questioned. However, the right set of structural variables believed to determine the appropriate framework for an analysis of the transition is yet to be found. 


\section{William Davidson Institute Working Paper 482}

\section{Data and Econometrics}

Data used to construct price indices, productivity measures, demand variables, and structural parameters cover 19 transition economies ${ }^{4}$. Each of the transition economies is observed from the start of the most serious stabilization attempt as defined by Fisher, Sahay, and Vegh (1996). This implies that the relative price of tradables in terms of non-tradables is set to 1 in the year of the most serious stabilization attempt. The implicit GDP deflator for industry in each country represents the price of tradables. Analogously, the implicit GDP deflator for services defines the price of non-tradables. The criterion for the period of observation was the year after which the relative price of tradables in terms of non-tradables has started to decline monotonously. However, this criterion has not been obeyed in all cases ${ }^{5}$. Different periods of observation were examined and compared to each other. The final observation periods for the unbalanced panel of 19 transition economies used in regressions are presented in Table 1. For all countries, the period of observation ends in 1998. The longest series runs from 1990 to 1998, while the shortest covers the period from 1995 to 1998. The largest sample includes 122 observations.

Additionally, Table 1 reveals the cumulative and average rate of appreciation during the observed period for individual countries as much as for the group of countries, which are believed to share common characteristics due to the progress of transition they experienced since the beginning of their reforms. The group of Central and Eastern Europe (CEE) consists of Bulgaria, Croatia, the Czech Republic, Hungary, Poland, Romania, the Slovak Republic, and Slovenia. The Baltic countries are Estonia, Latvia, and Lithuania. The countries of the former Soviet Union (FSU) are represented by Armenia, Azerbaijan, Belarus, Kazakhstan, Kyrgyzstan, Ukraine, and Uzbekistan. The possible similarities between Bulgaria, Romania, and the FSU were checked by inclusion of Bulgaria and Romania into the FSU group. In some cases, the inclusion of these two countries to the FSU group resulted in substantial differences as shown later. Again, the grouping of different transition countries is subjective and based on case studies. Also, Estonia was separated from the Baltic countries in a few regressions in order to check possible differences between Estonia, on one hand, and Latvia and Lithuania, on the other. In so doing, the possible similarities

\footnotetext{
${ }^{4}$ Armenia, Azerbaijan, Belarus, Bulgaria, Croatia, Czech Republic, Estonia, Hungary, Kazakhstan, Kyrgyzstan, Latvia, Lithuania, Poland, Romania, Russia, Slovak Republic, Slovenia, Ukraine, and Uzbekistan.

${ }^{5}$ Exceptions are Belarus, Romania, and Russia where the relative price of tradables has indeed increased. For these cases, the beginning of the observed period starts after the initial depreciation.
} 
William Davidson Institute Working Paper 482

Table 1: Cumulative Changes and Average Rates of Appreciation (In percent from the beginning of the observed period)

\begin{tabular}{|l|c|c|c|c|}
\hline Country & $\begin{array}{c}\text { Starting } \\
\text { Year }\end{array}$ & $\begin{array}{c}\text { Observed } \\
\text { Period }\end{array}$ & $\begin{array}{c}\text { Cumulative } \\
\text { Change of } \mathrm{P}_{\mathrm{T}} / \mathrm{P}_{\mathrm{N}}\end{array}$ & $\begin{array}{c}\text { Average Rate of } \\
\text { Appreciation }\end{array}$ \\
\hline Armenia & 1994 & 5 & -40.12 & -12.03 \\
\hline Azerbaijan & 1995 & 4 & -6.98 & -2.38 \\
\hline Belarus & 1994 & 5 & 28.18 & 6.40 \\
\hline Bulgaria & 1991 & 8 & -53.42 & -10.34 \\
\hline Croatia & 1993 & 6 & -13.03 & -2.75 \\
\hline Czech Republic & 1991 & 8 & -30.20 & -5.01 \\
\hline Estonia & 1990 & 9 & -43.17 & -7.96 \\
\hline Hungary & 1990 & 9 & -39.19 & -5.61 \\
\hline Kazakhstan & 1994 & 5 & -30.13 & -8.57 \\
\hline Kyrgyzstan & 1993 & 6 & -24.16 & -5.38 \\
\hline Latvia & 1993 & 6 & -26.20 & -5.90 \\
\hline Lithuania & 1992 & 7 & -21.67 & -3.99 \\
\hline Poland & 1990 & 9 & -53.77 & -9.59 \\
\hline Romania & 1993 & 6 & 2.11 & 0.42 \\
\hline Russia & 1994 & 5 & 0.76 & 0.19 \\
\hline Slovak Republic & 1991 & 8 & -26.87 & -4.37 \\
\hline Slovenia & 1992 & 7 & -9.10 & -1.58 \\
\hline Ukraine & 1994 & 5 & -46.79 & -14.59 \\
\hline Uzbekistan & 1994 & 5 & -5.31 & -1.36 \\
\hline
\end{tabular}

\begin{tabular}{|l|l|l|l|l|}
\hline CEE & & & -27.93 & -4.85 \\
\hline Baltics & & & -30.35 & -5.95 \\
\hline FSU & & & -19.96 & -4.72 \\
\hline
\end{tabular}

\begin{tabular}{|l|l|l|l|l|}
\hline $\begin{array}{l}\text { CEE without } \\
\text { BUL and ROM }\end{array}$ & & -28.69 & -4.82 \\
\hline $\begin{array}{l}\text { FSU with } \\
\text { BUL and ROM }\end{array}$ & & 122 & -17.59 & -4.76 \\
\hline $\begin{array}{l}\text { Total Number of } \\
\text { Observations }\end{array}$ & & & \\
\hline
\end{tabular}

Sources: World Bank; national authorities; and author's calculations. 


\section{William Davidson Institute Working Paper 482}

between Estonia and other CEE countries were examined. However, the results do not change significantly and confirm the stylized fact that the Baltics and CEE do share common characteristics of the transition process.

Table 1 shows that in all transition economies, except Belarus, Romania, and Russia, the real exchange rate has appreciated since the beginning of transition. The extent of appreciation varies from less than 10 percent cumulative since the beginning of transition in the case of Slovenia and Azerbaijan, to more than 50 percent in cumulative terms in Poland. The average rates of appreciation show the occurrence of early appreciations in the process of transition since the countries with the shortest track of transition process on average experience higher average rates of appreciation. Again, exceptions are Azerbaijan and Uzbekistan ${ }^{6}$. Financial crisis and political turbulence mainly determined the behavior of the real exchange rate in Romania and Russia at the end of 1997 and 1998. Since Belarus has maintained close trade ties with Russia throughout the transition period, the main explanation for the real exchange rate behavior in Belarus can be attributed to developments in Russia.

\subsection{Data Description}

For the purpose of the analysis, two sectors were distinguished: tradable and non-tradable. While theoretical literature on real exchange rates relies upon the division of commodities into tradables and nontradables, it is almost impractical to construct these two groups of commodities in reality. An obvious benchmark for tradability should be the extent to which the particular good is actually traded. For example, the sector is defined as tradable if more than 10 percent of total production is exported. In general, one would label manufactures as tradables and services as non-tradables. However, this is rather impossible at this stage in transition economies. In what follows, the tradable sector is represented by the industry sector, which includes manufacturing; gas, electricity, and water; mining and quarrying; and construction. The reason that all other sub-sectors besides manufacturing were included into the measure for the tradable sector was that for some countries, sectoral data and data on international trade flows were not available. To assure consistency, all tradable sectors in different countries include gas, electricity, water, mining and quarrying, and the construction sector although one could object their tradability. A more substantial problem arises from the inclusion of non-market services into the variable representing the non-tradable sector. However, the reasons for the inclusion of non-market services into the total services sector are the same as for the construction of the tradable sector variable. It is believed that on

${ }^{6}$ See Taube and Zettelmeyer (1998) for a detailed account on Uzbekistan. It is argued that Uzbekistan has experienced very mild transformation recession because of a relatively favorable sectoral output development (low degree of initial industrialization), an abundance of natural resources (especially cotton), and self-sufficiency in energy. 


\section{William Davidson Institute Working Paper 482}

average, these complications fade away although in specific cases, they could represent the main reason for different behavior of relative prices, as argued later.

The independent variable is the relative price of tradables in terms of the price of non-tradable goods. The implicit sectoral GDP deflators for industry and services are used to proxy the price indices in these two sectors. The relative price takes value 1 at the beginning of transition and enters the regressions in logarithms.

Data on the right-hand side of equation (33) fall into the following categories:

- Productivity measure. This variable is solely represented by the productivity differential between labor productivity in the production of tradable goods and labor productivity in the production of nontradables $\left(\left(\mathrm{a}_{\mathrm{T}}-\mathrm{a}_{\mathrm{N}}\right)_{\mathrm{i}, \mathrm{t}}\right)$. The productivity differential measures the extent of the Harrod-BalassaSamuelson effect on the real exchange rate. The rationale for using labor productivity instead of total factor productivity (TFP), which would theoretically follow from the specification of production function, is merely determined by the data availability. To construct the TFP measure, one would need reliable data on capital stock in transition economies, which is rather impossible since there are problems related to the physical extent of capital stock as much as to pricing of capital in these economies. This problem is especially relevant in measuring the capital stock in the service sector. For the time being, it is assumed that the labor productivity would consistently represent the effect of the productivity differential on the real exchange rate measure. The labor productivity variable was constructed from the sectoral GDP figures measured in constant prices divided by the labor employed in that sector. In the case of the non-tradable productivity variable, problems arise mainly form the inclusion of government services into the total services sector. On the other hand, tradable sector productivity suffers from the broader definition of the tradable sector. Usually, one would consider the tradable sector to be mainly represented by manufacturing. In the case of transition economy data, this sophistication was rather impossible. The productivity measures in both sectors, therefore, reflect the complications of data availability rather than conceptual issues. Data on sectoral GDP in constant prices were gathered from national accounts collected by World Bank desk economists. Labor data were obtained from ILO publications and from EBRD desk economists. The productivity differential variable enters equation (33) in logarithms.

- Demand variables. These variables consist of a share of non-tradable consumption in total private consumption ( share $_{i, t}$ ) and real government consumption measured in percent of GDP ( govreal $\left._{i, t}\right)$. The share of non-tradable consumption in total private consumption is believed to measure the shift of private consumption from tradables to non-tradables. It is expected that this variable should have a substantial impact on the relative prices in transition economies since product variety as much as the liberalization of economies have greatly improved since the beginning of transition. One possible 


\section{William Davidson Institute Working Paper 482}

explanation for the increased effect of private demand for non-tradables on the real exchange could be nested in a surge of capital flows to the region. Part of the capital inflows was directed to private consumption. Consequently, the price of non-tradable goods increased and caused the appreciation of the relative price of tradables. The change in the share of non-tradable consumption in total private consumption should, therefore, negatively affect the relative price of tradables in terms of nontradables. Government consumption is assumed to fall only on non-tradable goods. Therefore, the private consumption of non-tradables is equal to value added in services minus government consumption. Total private consumption is the sum of non-tradable and tradable consumption. The latter is equal to value added in tradable goods plus the deficit in the trade balance. De Gregorio, Giovannini, and Krueger (1993) argue that the nominal government expenditure over nominal GDP is by construction correlated with the real exchange rate. For this reason, the real government consumption over real GDP is used to construct the real government consumption measure ( govreal $_{\mathrm{i}, \mathrm{t}}$ ).

- Structural variable. As follows from the model, the preference of the central plan in the pre-transition period for the industry sector imposed a larger number of workers employed in industry compared to employment in services. Once the transition had started, the number of workers in industry declined while employment in services increased. To capture this effect, the structural variable $\left(l a b_{i, t}\right)$ was constructed by dividing the number of workers employed in industry by the number of workers employed in services. The same line of arguments for constructing this variable is relevant as in the case of constructing the tradable and non-tradable sectors. As transition progresses, the structural variable should decline and positively affect the relative price of tradables in terms of non-tradable goods. The reasons for a decline of the labor ratio throughout the transition process should be attributed to the structural changes in the transition economies, and thus exogenous to other right-hand side variables in the regression equation (33). To impose the latter, the structural variable $\left(l_{\mathrm{ab}} \mathrm{i}, \mathrm{t}\right)$ was instrumentalized by the structural reform index constructed by De Melo, Denizer and Gelb (1996) ${ }^{7}$, and total credit to the private sector (EBRD Transition Report, 1999). Also, the structural reform index itself was used in a few regressions to avoid possible mis-specification of the instrumental variable. However, the results do not differ significantly. Empirical work on growth in transition economies is mainly driven by the search of an appropriate set of variables that would distinguish transition economies from their developed counterparts, and that would more thoroughly explain the output behavior in the region. In the case of exchange rate behavior, this argument is even more pronounced.

The possible effects of explicit different initial conditions in transition economies was captured by specific country dummies, which reduced the regression analysis to the estimation of unbalanced panel data with fixed effects. Dynamic specification of equation (33) was not possible due to short time series, especially for the group of FSU countries.

\footnotetext{
${ }^{7}$ The updated structural reform index is presented in Havrylyshyn et al. (1999).
} 


\section{William Davidson Institute Working Paper 482}

\subsection{Determinants of Real Exchange Rate}

The three sets of explanatory variables are believed to affect the relative price of tradables in terms of non-tradables in the transition period. Visual inspection of data reveals the possible confirmation of the model. The average change in the relative price of tradables in terms of non-tradables is negatively correlated with the average change in productivity differential throughout the observed period. Figure 1 plots the average change in the relative price against the average annual change in the productivity differential, ${ }^{8}$ with Azerbaijan as a distinct outlier. The average change in both observed variables throughout the region suggests the possible long-run co-movement between the real exchange rate and productivity measure as suggested by the Harrod-Balassa-Samuelson effect explained earlier.

Figure 2 depicts the expected negative correlation between the real exchange rate and the share of non-tradable consumption in total private consumption. The number of outliers increases, suggesting that private demand factors may have played a different role across the region. On average, it seems that demand factors were more important in the determination of the real exchange rate in more advanced transition economies (CEE and the Baltics) than in the countries of the FSU. The possible explanation for this occurrence may lie in the fact that the more advanced transition economies were engaged longer in the transition

process.

\footnotetext{
${ }^{8}$ In this section, the productivity differential corresponds to a ratio between labor productivity in tradable goods production to labor productivity in non-tradables. The productivity ratio enters equation (33) in logs and becomes the productivity differential. In order not to use too many different expressions for the same variable, the notion of productivity differential will be used in this section.
} 


\section{William Davidson Institute Working Paper 482}

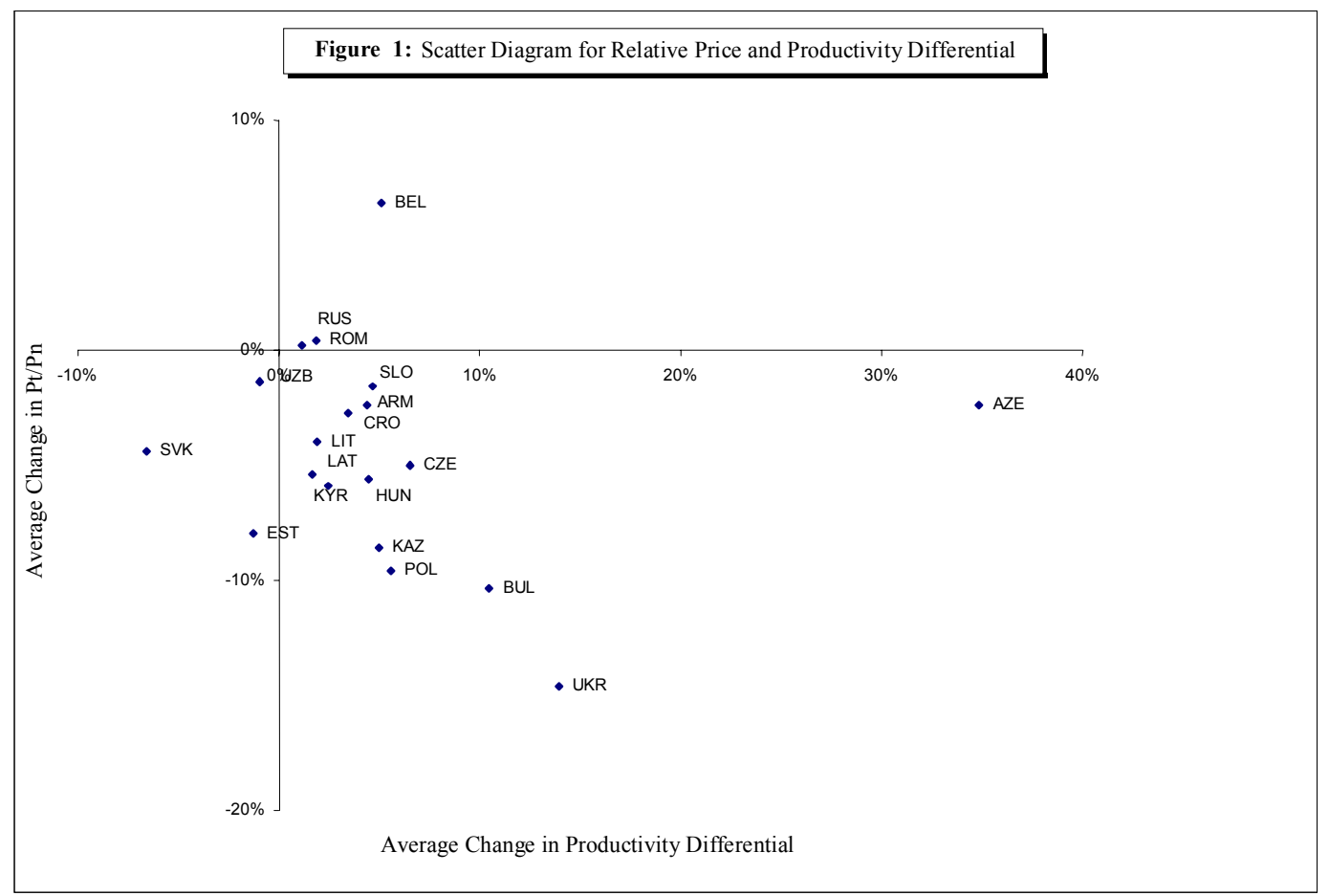

Sources: The World Bank; and author's calculations.

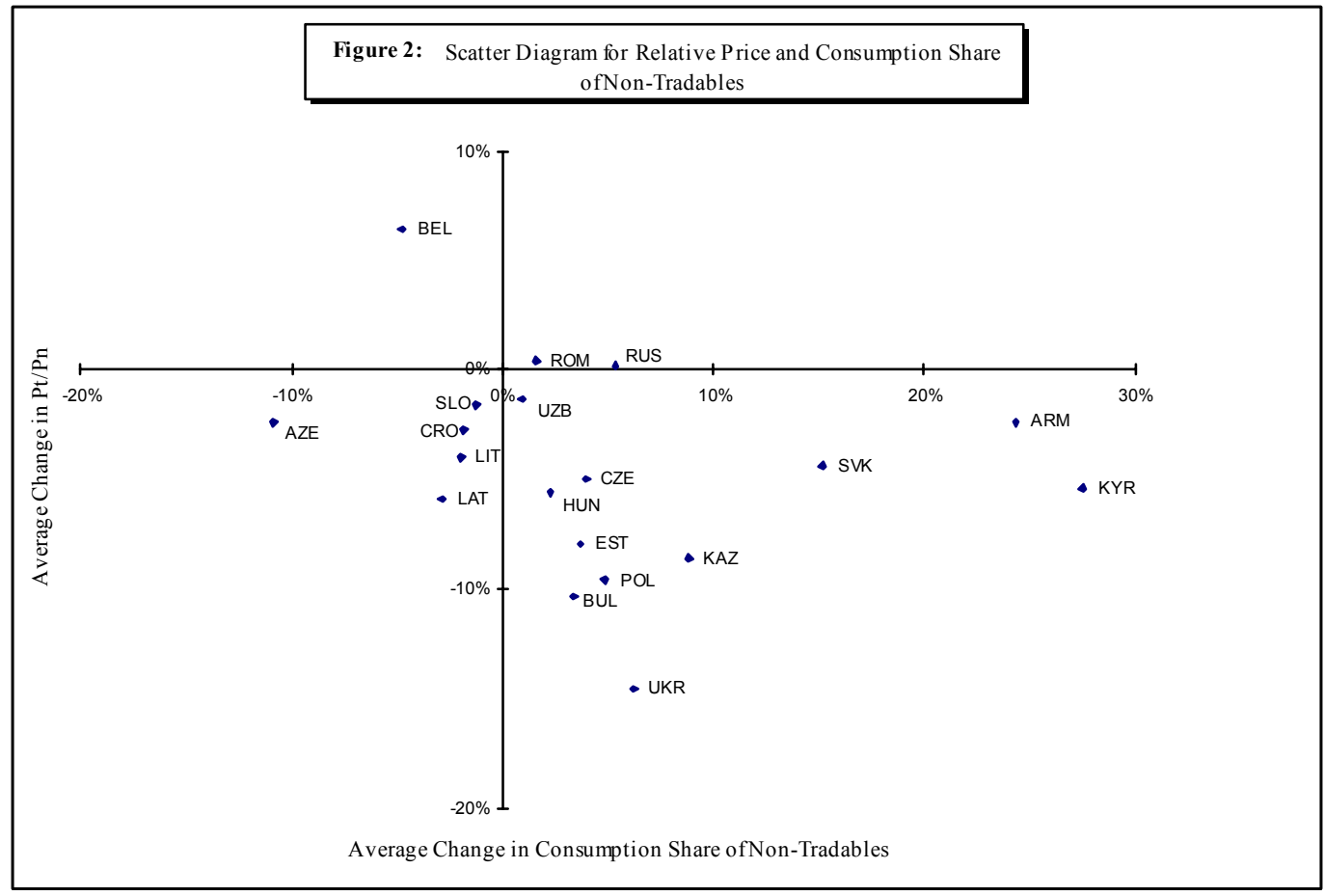

Sources: The World Bank; and author's calculations. 


\section{William Davidson Institute Working Paper 482}

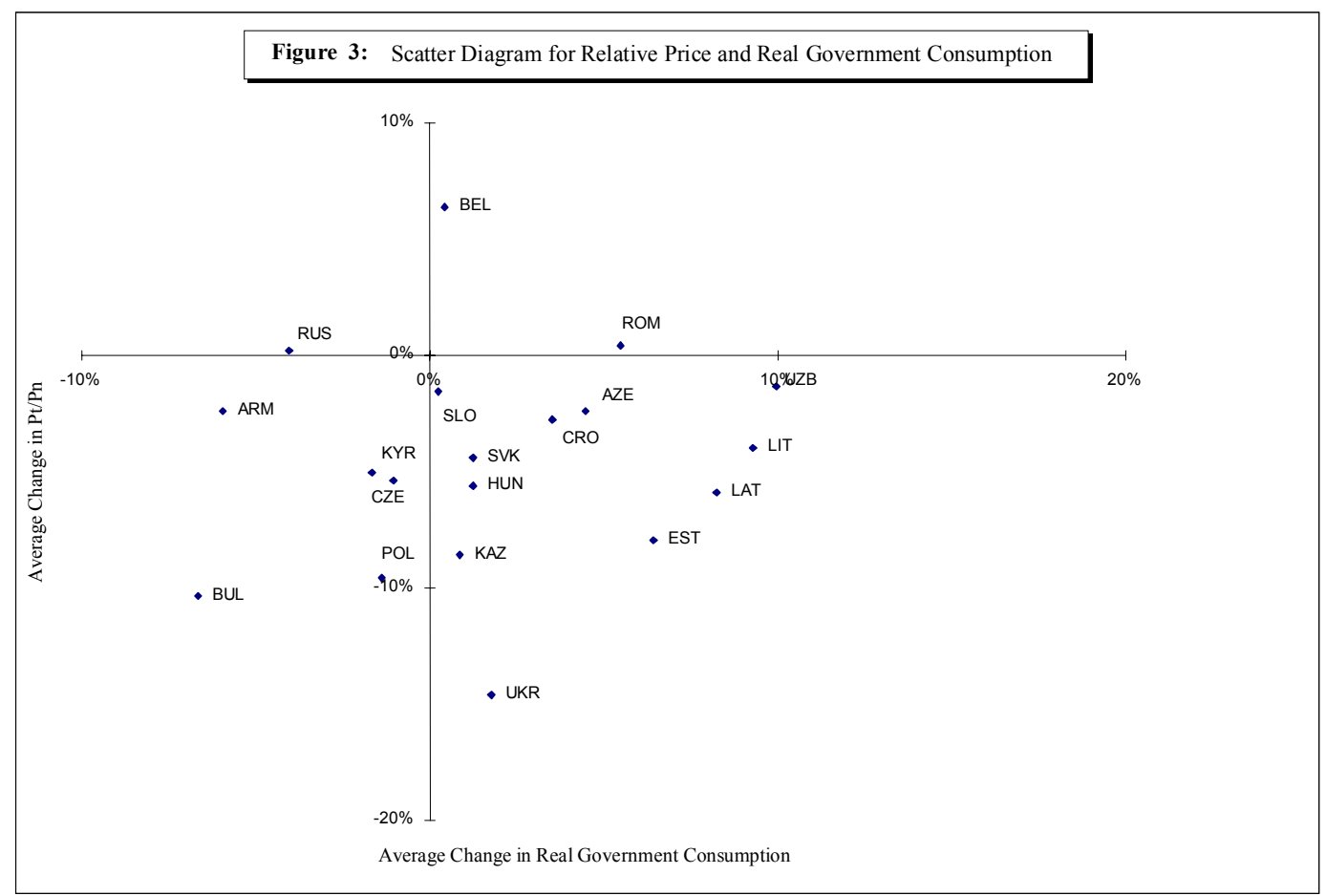

Sources: The World Bank; and author's calculations.

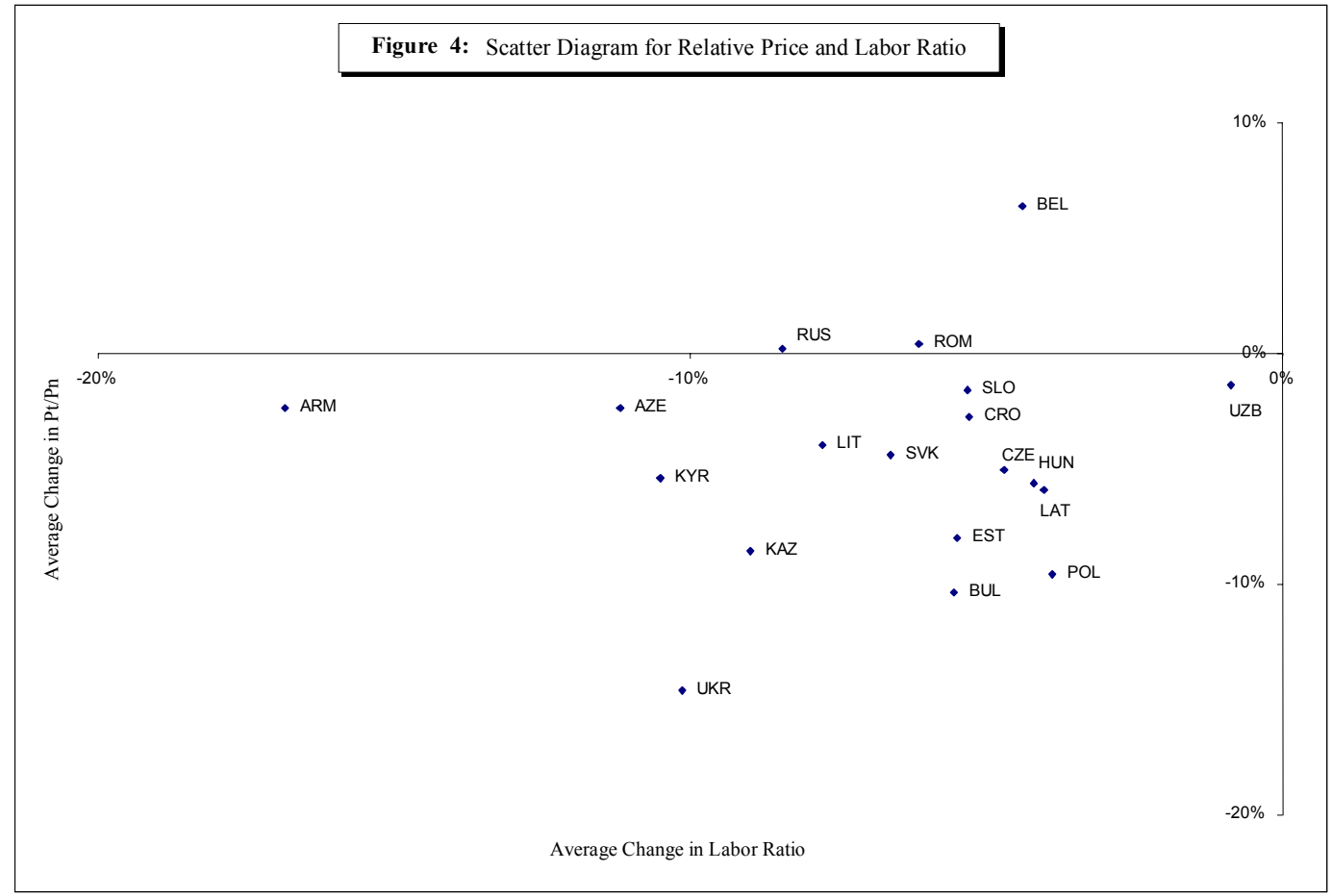

Sources: The World Bank; and author's calculations. 


\section{William Davidson Institute Working Paper 482}

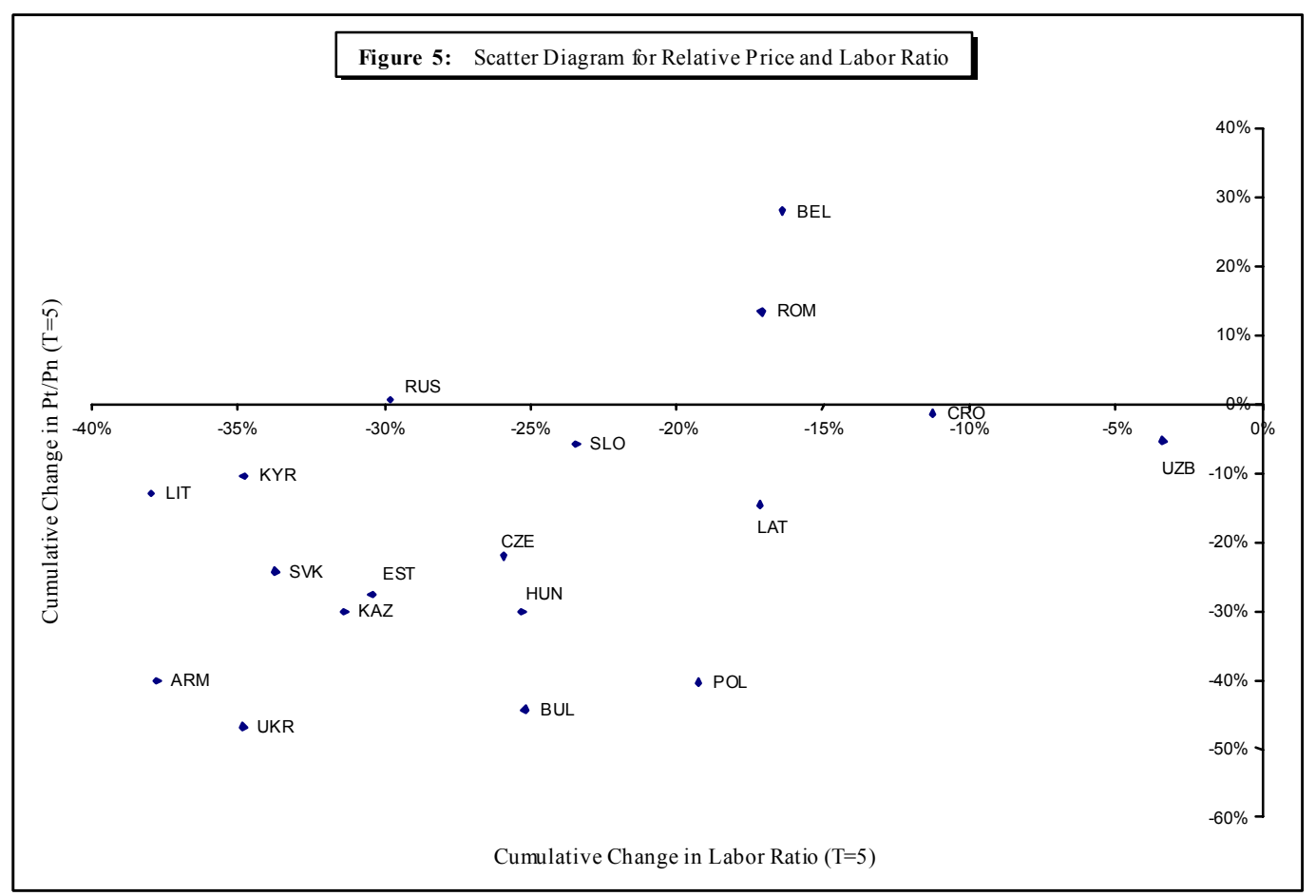

Source: The World Bank; and author's calculations. 


\section{William Davidson Institute Working Paper 482}

As the output performance has improved at the latter stages of transition, the private consumption demand has consequently built up, contributing to a more appreciated value of the price of tradables relative to the price of non-tradable goods.

Figure 3 reveals a different role of government in the transition process in accordance to the behavior of the real exchange rate. Graphical exposition of the annual change in the relative price of tradables in terms of non-tradables against real government consumption does not indicate any strong correlation between the average annual changes in the respective variables. Though, it seems that the negative correlation between the real exchange rate and government consumption was the strongest in the Baltic countries. This fact comes as no surprise since the Baltic countries emerged in transition as independent countries with a strong inclination to separate from the FSU countries. A similar line of argument could be drawn for Croatia, the Czech Republic, the Slovak Republic, and Slovenia. However, for this group of countries, it is argued that they entered transition with more sophisticated government infrastructure than the Baltic countries. In the case of the Czech Republic, even a slight negative growth of real government consumption growth is observed. Again, as a group, only the Baltic countries seem to differ from the region. In the econometric part of this paper, the formative conclusions based on Figure 3 are generally confirmed.

A plot between the annual average change in the relative price and the change in the labor ratio of tradable employment to non-tradable employment is presented in Figure 4. Bulgaria, the Czech Republic, Estonia, Hungary, and Poland can be singled out as the group of countries with the longest track of transition. They started with transition as early as 1990, which presents at least two to three years' advantage to other transition economies. The duration of transition seems to diminish the role of the structural variable in affecting the real exchange rate. The conclusion follows naturally from the fact that most structural changes indeed occurred at the beginning of transition. If the duration of transition time is limited to five years (all countries except Azerbaijan, which started with transition in 1995, classify in this grouping), then the positive correlation between the cumulative change in the real exchange rate plotted against the cumulative change in the labor ratio turns out to be more pronounced. This plot is depicted in Figure 5.

Special attention should be paid to productivity differential and labor ratio variables since they appear to be highly volatile across countries and time. Table 2 reports the mean and standard deviation of the log of productivity differential and the labor ratio for all 19 countries. The results are quite dispersed for the productivity differential variable ranging from below 1 to above 2 and in the case of Azerbaijan, above 3. For this reason, the productivity differential enters the regression equation (33) in the natural logarithm of 1 plus the productivity differential expressed as a decimal. In so doing, the sign of the logarithm is always positive, assuring the comparison across countries. Additionally, there is a suspicion

on these two variables of being endogenous and highly correlated apart from the possible endogenous 
William Davidson Institute Working Paper 482

Table 2: Means and Standard Deviations for Productivity Differential and Labor Ratio

\begin{tabular}{|l|c|c|c|c|}
\hline \multirow{2}{*}{ Country } & \multicolumn{2}{|c|}{ Productivity Differential } & \multicolumn{2}{c|}{ Labor Ratio } \\
\cline { 2 - 5 } & Mean & St. Dev. & Mean & St. Dev. \\
\hline Armenia & 2.563 & 0.218 & 0.670 & 0.137 \\
\hline Azerbaijan & 3.563 & 1.314 & 0.308 & 0.079 \\
\hline Belarus & 0.982 & 0.072 & 0.793 & 0.066 \\
\hline Bulgaria & 1.335 & 0.267 & 0.843 & 0.119 \\
\hline Croatia & 0.942 & 0.083 & 0.699 & 0.066 \\
\hline Czech Republic & 1.347 & 0.213 & 0.858 & 0.114 \\
\hline Estonia & 1.259 & 0.089 & 0.682 & 0.117 \\
\hline Hungary & 1.316 & 0.197 & 0.614 & 0.072 \\
\hline Kazakhstan & 1.891 & 0.186 & 0.415 & 0.072 \\
\hline Kyrgyzstan & 2.111 & 0.250 & 0.438 & 0.082 \\
\hline Latvia & 1.145 & 0.068 & 0.526 & 0.050 \\
\hline Lithuania & 1.252 & 0.082 & 0.642 & 0.130 \\
\hline Poland & 1.621 & 0.275 & 0.754 & 0.082 \\
\hline Romania & 0.990 & 0.068 & 1.101 & 0.119 \\
\hline Russia & 1.113 & 0.085 & 0.653 & 0.094 \\
\hline Slovak Republic & 1.180 & 0.270 & 0.739 & 0.123 \\
\hline Slovenia & 0.865 & 0.091 & 0.859 & 0.105 \\
\hline Ukraine & 1.956 & 0.408 & 0.608 & 0.110 \\
\hline Uzbekistan & 1.257 & 0.019 & 0.553 & 0.012 \\
\hline
\end{tabular}

\begin{tabular}{|l|l|l|l|l|}
\hline All Countries & 1.449 & 0.627 & 0.689 & 0.192 \\
\hline
\end{tabular}

\begin{tabular}{|l|l|l|l|l|}
\hline CEE & 1.229 & 0.311 & 0.797 & 0.163 \\
\hline Baltics & 1.226 & 0.093 & 0.626 & 0.122 \\
\hline FSU & 1.893 & 0.869 & 0.552 & 0.166 \\
\hline
\end{tabular}

\begin{tabular}{|l|c|c|c|c|}
\hline $\begin{array}{l}\text { CEE without } \\
\text { BUL and ROM }\end{array}$ & 1.242 & 0.324 & 0.751 & 0.127 \\
\hline $\begin{array}{l}\text { FSU with } \\
\text { BUL and ROM }\end{array}$ & 1.710 & 0.819 & 0.660 & 0.245 \\
\hline
\end{tabular}

Sources: The World Bank; and author's calculations. 


\section{William Davidson Institute Working Paper 482}

and highly correlated apart from the possible endogeneity between demand variables and labor ratio. The labor demand from the non-tradable sector should increase as the result of the increase in demand for nontradables. Hence, the two variables should be positively correlated. If one abstracts for the moment from the direct link between product and factor demand in transition economies, one cannot as easily assume away the possible correlation between productivity growth in the tradable sector and labor demand in the same sector.

For these reasons, the structural variable approximated by the ratio between labor employed in the tradable sector and labor employed in the non-tradable sector was instrumentalized by the structural reform index and credit to the private sector in transition economies. In few regressions, only the structural reform index was used. The results, however, did not change substantially. The structural reform index was originally constructed by de Melo, Denizer, and Gelb (1996) and covered the period from 1990 to 1996. The updates from 1996 are constructed on the basis of the EBRD Transition Reports $(1997,1998)$ and presented in Havrylyshyn et al. (1999). The structural reform index is a weighting average of three sub-indices: the index on internal liberalization, which scores price liberalization and the dismantling of trading monopolies in domestic markets; the index on external liberalization, which measures the removal of trade controls and quotas, moderation of tariff rates, and foreign exchange restrictions; and the index on private sector conditions, which measures the progress in privatization and financial sector reforms (de Melo, Denizer, and Gelb, 1996; Berg et al., 1999).

\subsection{Econometric Methodology}

Equation (33) is estimated by Ordinary Least Squares (OLS) for the unbalanced panel of 122 observations. To capture the differences across units, the Least Squares Dummy Variable (LSDV) econometric technique was employed. Conceptually, the LSDV is argued to be the appropriate econometric approach in the case of high heterogeneity among individual entries in the panel data set. In the case of transition economies, this argument is plausible once the differences in the initial conditions and structural reforms employed in transition economies are taken into account. Moreover, in the case of real exchange rate determination, where the real exchange rate is normalized to the value of 1 at the beginning of transition, while other variables enter equation (33) not in the form of an index measure, the fixed-effects model is the only approach to be employed in order to maintain quality of the estimated parameters.

The obvious generalization of this approach is to introduce dummy variables to account for the effects of those omitted variables that are specific to individual cross-sectional units and time period. If 


\section{William Davidson Institute Working Paper 482}

constant terms, $\alpha_{i}$, is an unknown parameter to be estimated, and $\mathbf{y}_{\mathrm{i}}$ and $\mathbf{X}_{\mathrm{i}}$ are T observations for the i-th unit, then the regression equation to be estimated is written as:

$$
\mathbf{y}_{\mathrm{i}, \mathrm{t}}=\mathbf{d u m m y} * \alpha_{\mathrm{i}}+\mathbf{X}_{\mathrm{i}, \mathrm{f}} \boldsymbol{\beta}+\varepsilon_{\mathrm{i}, \mathrm{t}}
$$

where the value of the dependent variable for the $\mathrm{i}$-th unit at time $\mathrm{t}, \mathbf{y}_{\mathrm{i}, \mathrm{t}}$, depends on $\mathrm{K}$ exogenous variables, $\mathbf{X}_{\mathrm{i}, \mathrm{t}}$, that differ among individuals in a cross section at a given point in time. The vector $\boldsymbol{\beta}$ is a vector of constants and the error term, $\varepsilon_{\mathrm{i}, \mathrm{t}}$, represents the effects of the omitted variables that are peculiar to both the individual units and time periods. The multiplicative term, dummy* $\alpha_{i}$, represents the effects of those variables peculiar to the $\mathrm{i}$-th individual in more or less the same fashion over time. In our case, the dummy vector represents 19 individual countries entering the panel data.

In some regressions, individual multiplicative dummies for groups of transition economies are used to capture the possible different effects of certain independent variables on the real exchange rate determination. Special attention is paid to the differences between more advanced transition economies (CCE and the Baltics) and FSU countries. To test these restrictions, the Wald test is employed. The Wald statistic measures how close the unrestricted estimates come to satisfying the restrictions under the null hypothesis, which in this case, is that the coefficients are the same. If the restrictions are in fact true, then the unrestricted estimates should come close to satisfying the restrictions.

In Section 5.2, time dummies are employed in the estimation of equation (33) instead of country specific dummies. Time dummies are introduced in order to capture the possible differences across the region with the reference to the time spent in transition. Moreover, in the case of country-specific effects, the degrees of freedom are significantly reduced. In a sample with a relatively small number of observations, this may cast doubts on the consistency of estimated parameters. When time dummies are used instead of country specific dummies, the number of degrees of freedom increases by the difference between the time and country specific dummies. Additionally, by an inclusion of time dummies, the robustness of the model is examined against the model with country specific effects. 


\section{William Davidson Institute Working Paper 482}

\section{Empirical Results}

Table 3a reproduces the results of the regression of equation (33) for the full sample of 19 economies, each observed in the transition time as specified in Table 1. The total number of observations is 122. Coefficient estimates are reported with t-statistics in parenthesis. Superscripts indicate their possible insignificance at a 5 percent level $^{9}$ of confidence. Country-specific dummies are reported in Table $3 \mathrm{~b}$, and are significant in most of the specifications. The results of the basic equation (A.1) in Table 3a produce the earlier findings that the productivity differential, the share of non-tradable consumption in total private consumption, and real government consumption negatively affect the real exchange rate, thus contributing to the real appreciation. The labor ratio between labor employed in tradables to labor employed in non-tradable goods production enters the regression with a

positive sign as predicted by the model. This suggests that the delay in structural reforms - relatively high values of the labor ratio variable at the beginning of transition relative to its end values - in general tends to act as a restraining force on the real exchange rate.

Table $3 \mathrm{~b}$ shows the country-specific constants of the fixed-effects panel estimates. The dispersion of these constants is quite large, as indicated by the range from the highest to lowest value and by their standard deviation. In effect, it appears that the country-specific constants act like country dummies, increasing the goodness of fit, but it is difficult to give objective interpretation of the factors explaining the variation in economic performance among countries.

To test for possible differences across regions (CEE, Baltics, and FSU), multiplicative dummies are added to the basic regression (A.1). In so doing, it is argued that significant coefficients on multiplicative dummies would reflect different effects of single variables on determination of the real exchange rate across regions. As expected, results are not very satisfactory, which can mostly be accounted to relative short time series, and more importantly, that on average, there were no significant differences across countries. This conclusion may come as a surprise; however, on average the dynamics of different independent variables were not substantially different when the process of transition is measured in transition time from the beginning of the most serious stabilization plan implemented in each country.

\footnotetext{
${ }^{9}$ Tests on whether a coefficient differs significantly from zero in the expected direction are based on one tailed t-tests and a 5 percent confidence interval which, for an infinite number of degrees of freedom, involves an absolute value of $t$ greater than 1.98 .
} 
William Davidson Institute Working Paper 482

Table 3a: Fixed-Effects Panel Estimates $\left(\mathrm{Lab}_{\mathrm{i}, \mathrm{t}}\right)$

(Start of reforms - 1998)

\begin{tabular}{|l|c|c|c|c|c|c|c|}
\hline & \multicolumn{7}{|c|}{ Dependent Variable: $\log \left(\mathrm{P}_{\mathrm{T}} / \mathrm{P}_{\mathrm{N}}\right)_{\mathrm{i}, \mathrm{t}}$} \\
\hline Variable & $(\mathrm{A} .1)$ & $(\mathrm{A} .2)$ & $(\mathrm{A} .3)$ & $(\mathrm{A} .4)$ & $(\mathrm{A} .5)$ & $(\mathrm{A} .6)$ & $(\mathrm{A} .7)$ \\
\hline \multirow{2}{*}{$\log \left(\mathrm{a}_{\mathrm{T}}-\mathrm{a}_{\mathrm{N}}\right)_{\mathrm{i}, \mathrm{t}}$} & $-0.868^{*}$ & $-1.332^{*}$ & $-0.888^{*}$ & $-0.869^{*}$ & $-0.885^{*}$ & $-1.175^{*}$ & $-0.890^{*}$ \\
& $(0.169)$ & $(0.141)$ & $(0.177)$ & $(0.173)$ & $(0.171)$ & $(0.126)$ & $(0.176)$ \\
\hline \multirow{2}{*}{ Share $_{\mathrm{i}, \mathrm{t}}$} & $-1.656^{*}$ & $-1.854^{*}$ & $-1.685^{*}$ & $-1.672^{*}$ & $-1.663^{*}$ & $-1.568^{*}$ & $-1.695^{*}$ \\
& $(0.219)$ & $(0.233)$ & $(0.187)$ & $(0.195)$ & $(0.218)$ & $(0.212)$ & $(0.236)$ \\
\hline \multirow{2}{*}{ Govreal $_{\mathrm{i}, \mathrm{t}}$} & $-0.749^{*}$ & $-1.595^{*}$ & $-0.711^{*}$ & $-0.762^{*}$ & -0.682 & $-0.812^{*}$ & $-0.635^{*}$ \\
\hline \multirow{2}{*}{ Lab $_{\mathrm{i}, \mathrm{t}}$} & $(0.379)$ & $(0.497)$ & $(0.754)$ & $(0.389)$ & $(0.737)$ & $(0.401)$ & $(0.360)$ \\
\hline
\end{tabular}

\begin{tabular}{|c|c|c|l|l|l|l|l|}
\hline Baltics & & & & & & & \\
\hline Lab*Bal & & $1.035^{*}$ & & & & & 0.471 \\
& $(0.273)$ & & & & & $(0.189)$ \\
\hline Share*Bal & & 0.200 & -0.180 & -0.071 & & & \\
& $(0.517)$ & $(0.539)$ & $(0.572)$ & & & \\
\hline Prod*Bal & & $-1.476^{*}$ & & & & -1.002 & \\
\hline Gov*Bal & & $(0.694)$ & & & & $(0.714)$ & \\
& & $1.313^{*}$ & -0.504 & & -0.492 & & \\
\hline
\end{tabular}

\begin{tabular}{|c|c|c|c|c|c|c|c|}
\hline FSU & & & & & & & \\
\hline Lab*FSU & & $1.757^{*}$ & & & & & 0.301 \\
$(0.734)$ & & & & & $(0.575)$ \\
\hline Share*FSU & & 0.594 & 0.092 & 0.056 & & & \\
\hline Prod*FSU & & $(0.549)$ & $(0.434)$ & $(0.415)$ & & & \\
\hline Gov*FSU & & $\left(0.2735^{*}\right.$ & & & & $0.729^{*}$ & \\
& & $1.829^{*}$ & 1.099 & & 1.038 & & \\
\hline
\end{tabular}

\begin{tabular}{|c|c|c|c|c|c|c|c|}
\hline Adj. $\mathrm{R}^{2}$ & 0.853 & 0.886 & 0.851 & 0.850 & 0.883 & 0.876 & 0.851 \\
\hline $\mathrm{N}$ & 122 & 122 & 122 & 122 & 122 & 122 & 122 \\
\hline
\end{tabular}

Note: Numbers in parentheses are t-ratios based on heteroscedasticity-adjusted standard errors. The * indicates that the coefficient is significantly greater or smaller than zero, as appropriate, at a 5 percent level. 
William Davidson Institute Working Paper 482

Table 3b: Fixed-Effects Panel Estimates - Country-Specific Dummies

\begin{tabular}{|l|c|c|c|c|c|c|c|}
\hline \multirow{2}{*}{ Country } & \multicolumn{7}{|c|}{ Regression } \\
\cline { 2 - 8 }$(\mathrm{A} .1)$ & $(\mathrm{A} .2)$ & $(\mathrm{A} .3)$ & $(\mathrm{A} .4)$ & $(\mathrm{A} .5)$ & $(\mathrm{A} .6)$ & $(\mathrm{A} .7)$ \\
\hline Armenia & 0.726 & 0.277 & 1.617 & 1.713 & 1.633 & 1.006 & 1.762 \\
\hline Azerbaijan & 1.721 & -0.941 & 0.682 & 0.724 & 0.685 & 0.031 & 0.773 \\
\hline Belarus & 0.917 & -0.731 & 0.719 & 0.909 & 0.734 & 0.435 & 0.941 \\
\hline Bulgaria & 0.665 & 1.811 & 0.765 & 0.679 & 0.734 & 0.704 & 0.965 \\
\hline Croatia & 0.797 & 1.878 & 0.869 & 0.810 & 0.841 & 0.841 & 1.019 \\
\hline Czech Republic & 0.697 & 1.891 & 0.792 & 0.711 & 0.763 & 0.753 & 0.989 \\
\hline Estonia & 0.747 & 1.803 & 1.017 & 0.789 & 0.913 & 1.641 & 0.660 \\
\hline Hungary & 1.026 & 2.026 & 1.109 & 1.040 & 1.081 & 1.109 & 1.254 \\
\hline Kazakhstan & 1.338 & -0.084 & 1.218 & 1.320 & 1.251 & 0.757 & 1.383 \\
\hline Kyrgyzstan & 1.061 & -0.392 & 0.877 & 1.022 & 0.893 & 0.473 & 1.089 \\
\hline Latvia & 1.184 & 2.184 & 1.495 & 1.229 & 1.384 & 2.049 & 1.106 \\
\hline Lithuania & 1.039 & 2.116 & 1.299 & 1.079 & 1.201 & 1.941 & 0.958 \\
\hline Poland & 0.741 & 1.891 & 0.833 & 0.754 & 0.805 & 0.843 & 1.010 \\
\hline Romania & 0.598 & 1.779 & 0.715 & 0.611 & 0.686 & 0.546 & 0.979 \\
\hline Russia & 1.218 & -0.310 & 1.098 & 1.201 & 1.129 & 0.717 & 1.262 \\
\hline Slovak Republic & 0.803 & 1.888 & 0.888 & 0.816 & 0.859 & 0.856 & 1.057 \\
\hline Slovenia & 0.829 & 1.933 & 0.923 & 0.844 & 0.892 & 0.806 & 1.122 \\
\hline Ukraine & 0.879 & -0.778 & 0.673 & 0.873 & 0.690 & 0.276 & 0.909 \\
\hline Uzbekistan & 1.159 & -0.365 & 0.873 & 1.151 & 0.897 & 0.678 & 1.177 \\
\hline & & & & & & \\
\hline Average & 0.955 & 0.941 & 0.972 & 0.962 & 0.951 & 0.866 & 1.074 \\
\hline Highest & 1.721 & 2.184 & 1.617 & 1.713 & 1.633 & 2.049 & 1.762 \\
\hline Lowest & 0.598 & -0.941 & 0.673 & 0.611 & 0.685 & 0.031 & 0.660 \\
\hline Std. Dev. & 0.280 & 1.218 & 0.272 & 0.273 & 0.263 & 0.518 & 0.236 \\
\hline
\end{tabular}


Regression (A.2) adds 8 interaction terms to test for different joint effects of independent variables on real exchange rate determination among three groups of transition countries. As expected, most of the interaction terms are not significant. A joint Wald-test on the significance of all Baltics and FSU dummies, respectively, cannot reject the null hypothesis of all respective country-dummy coefficients being zero. F-statistics on joint Baltics dummies is equal to 3.991; while F-statistics on joint FSU dummies is slightly higher, 4.396, but still not big enough to reject the null hypothesis.

To test for the significance of individual pairs of interaction terms, regressions from (A.3) to (A.7) are employed. In so doing, the possible isolated effects of independent variables on the real exchange rate across different groups of countries are examined. To test a joint effect of demand variables on real exchange rate determination, regression (3) adds four multiplicative dummies, two for each group of countries. Again, the coefficients on real government consumption and private non-tradable consumption are not significantly different from zero, although they are correctly signed. It is argued later that demand variables played a more important role in determining the real exchange rate in the Baltics than in other regions. A negative sign of coefficient on demand variables in the Baltics corresponds to this line of argument.

Regressions (A.4) and (A.5) separately test the significance of the effect of private nontradable and government consumption, respectively on the real exchange rate in the Baltic countries and the FSU. The results are along the line of regression (A.3) and just replicate the conclusions from regression (A.3). Again, the results are expected - although statistically insignificant - especially for the government variable, as the Baltic countries have struggled to establish the sovereignty from the Soviet Union in the early days of transition and strengthened the role of government in the economy.

Inclusion of dummies on productivity measures produces regression (A.6). The results indicate that on average, the productivity differential played a less important role in determining real exchange rates in the FSU than in the CEE and Baltic countries.

Regression (A.7) tests for possible differences in real exchange rate determination with respect to the effect of structural parameters. All three coefficients on structural reform variables are not significantly different from zero. The results from regression (A.7) are not surprising to the point that on average, the transition countries began with the transition process along the same 
lines of implementation of reforms. As empirical models on growth in transition show, all transition economies were sequencing their reforms from macroeconomic stabilization via microeconomic liberalization to institutional building. All variables in the model are normalized to the beginning of the stabilization program in each economy; for that reason the sequencing of reform should be the same in all countries, if one accepts the assumption that all countries followed the same stabilization program. As most transition countries accepted the external technical assistance provided by the World Bank or the International Monetary Fund, the assumption on similarities of the transition process becomes plausible.

In general, separate regressions confirm the conclusions from regression (A.2) where all dummies are included. However, the suspicion on the possible endogeneity and multicollinearity, especially between productivity measure and structural parameter, leads us to replicate the regressions in Table 3a by substituting the labor ratio variable with the structural reform index. In addition, all regressions in Table $3 \mathrm{a}$ are run with country-specific constants, which take out most of the unobserved effects on the real exchange rate appreciation. For that reason, the fit of regressions is extremely good. However, one could argue that because of different initial conditions observed in transition economies at the beginning of transition, it is reasonable to account for those differences by including country-specific dummies. Table $4 \mathrm{a}$, therefore, reproduces the regressions from Table $3 \mathrm{a}$ with the structural reform index instead of the labor ratio to account for the extent of structural reforms in transition economies.

The country-specific effects presented in Table $4 \mathrm{~b}$ correspond to fixed-effects panel estimates in Table 4a. The dispersion of these constants is still quite large; however, it is small relative to the corresponding constants in Table $3 \mathrm{~b}$, where structural reforms were proxied by the labor ratio. This result is not surprising, as the structural reform index is normalized to take values between zero and 1, while the labor ratio is dispersed among countries as indicated in Table 2. 
William Davidson Institute Working Paper 482

Table 4a: Fixed-Effects Panel Estimates (Reform $\left.{ }_{i, t}\right)$

(Start of reforms - 1998)

\begin{tabular}{|c|c|c|c|c|c|c|c|}
\hline & \multicolumn{7}{|c|}{ Dependent Variable: $\log \left(\mathrm{P}_{\mathrm{T}} / \mathrm{P}_{\mathrm{N}}\right)_{\mathrm{i}, \mathrm{t}}$} \\
\hline Variable & (B.1) & (B.2) & (B.3) & (B.4) & (B.5) & (B.6) & (B.7) \\
\hline $\log \left(a_{T}-a_{N}\right)_{i, t}$ & $\begin{array}{l}-0.866^{*} \\
(0.167)\end{array}$ & $\begin{array}{l}-1.288^{*} \\
(0.151)\end{array}$ & $\begin{array}{l}-0.869^{*} \\
(0.176)\end{array}$ & $\begin{array}{l}-0.855^{*} \\
(0.174)\end{array}$ & $\begin{array}{l}-0.868^{*} \\
(0.167)\end{array}$ & $\begin{array}{l}-1.177^{*} \\
(0.133)\end{array}$ & $\begin{array}{l}-0.920^{*} \\
(0.165)\end{array}$ \\
\hline Share $_{i, t}$ & $\begin{array}{l}-1.737 * \\
(0.203)\end{array}$ & $\begin{array}{l}-1.844^{*} \\
(0.214)\end{array}$ & $\begin{array}{l}-1.825^{*} \\
(0.167)\end{array}$ & $\begin{array}{l}-1.860^{*} \\
(0.178)\end{array}$ & $\begin{array}{l}-1.715^{*} \\
(0.199)\end{array}$ & $\begin{array}{l}-1.667^{*} \\
(0.210)\end{array}$ & $\begin{array}{l}-1.788^{*} \\
(0.214)\end{array}$ \\
\hline Govreal $_{\mathrm{i}, \mathrm{t}}$ & $\begin{array}{l}-0.632 * \\
(0.371)\end{array}$ & $\begin{array}{l}-1.387^{*} \\
(0.589)\end{array}$ & $\begin{array}{l}-0.407 \\
(0.715)\end{array}$ & $\begin{array}{l}-0.649 \\
(0.401)\end{array}$ & $\begin{array}{l}-0.286 \\
(0.723)\end{array}$ & $\begin{array}{l}-0.622 * \\
(0.368)\end{array}$ & $\begin{array}{l}-0.592 \\
(0.373)\end{array}$ \\
\hline Reform $_{\mathrm{i}, \mathrm{t}}$ & $\begin{array}{l}-0.399^{*} \\
(0.116)\end{array}$ & $\begin{array}{l}-0.181 \\
(0.187)\end{array}$ & $\begin{array}{c}-0.369^{*} \\
(0.123)\end{array}$ & $\begin{array}{c}-0.424 * \\
(0.128) \\
\end{array}$ & $\begin{array}{l}-0.352^{*} \\
(0.110)\end{array}$ & $\begin{array}{l}-0.558^{*} \\
(0.149)\end{array}$ & $\begin{array}{l}-0.359^{*} \\
(0.201)\end{array}$ \\
\hline
\end{tabular}

\begin{tabular}{|c|c|c|l|l|l|l|l|}
\hline Baltics & & & & & & & \\
\hline Ref*Bal & & $-0.622^{*}$ & & & & & -0.144 \\
& $(0.240)$ & & & & & $(0.213)$ \\
\hline Share*Bal & & 0.136 & -0.047 & 0.121 & & & \\
\hline Prod*Bal & & $(0.481)$ & $(0.554)$ & $(0.604)$ & & & \\
\hline Gov*Bal & & $-1.491^{*}$ & & & & -0.995 & \\
& $(0.688)$ & & & & $(0.699)$ & \\
\hline
\end{tabular}

\begin{tabular}{|c|c|c|l|l|l|l|l|}
\hline FSU & & & & & & & \\
\hline Ref*FSU & & -0.708 & & & & & 0.265 \\
& $(0.504)$ & & & & & $(0.310)$ \\
\hline Share*FSU & & 0.664 & 0.319 & 0.342 & & & \\
\hline Prod*FSU & & $(0.587)$ & $(0.452)$ & $(0.439)$ & & & \\
\hline Gov*FSU & & $0.935^{*}$ & & & & $0.747^{*}$ & \\
& & $(0.293)$ & & & & $(0.208)$ & \\
\hline
\end{tabular}

\begin{tabular}{|c|c|c|c|c|c|c|c|}
\hline Adj. $\mathrm{R}^{2}$ & 0.851 & 0.877 & 0.851 & 0.849 & 0.853 & 0.874 & 0.851 \\
\hline $\mathrm{N}$ & 122 & 122 & 122 & 122 & 122 & 122 & 122 \\
\hline
\end{tabular}

Note: Numbers in parentheses are t-ratios based on heteroscedasticity-adjusted standard errors. The * indicates that the coefficient is significantly greater or smaller than zero, as appropriate, at a 5 percent level. 
Table 4b: Fixed-Effects Panel Estimates - Country-Specific Dummies

\begin{tabular}{|l|c|c|c|c|c|c|c|}
\hline \multirow{2}{*}{ Country } & \multicolumn{7}{|c|}{ Regression } \\
\cline { 2 - 8 } & $(\mathrm{B} .1)$ & $(\mathrm{B} .2)$ & $(\mathrm{B} .3)$ & $(\mathrm{B} .4)$ & $(\mathrm{B} .5)$ & $(\mathrm{B} .6)$ & $(\mathrm{B} .7)$ \\
\hline Armenia & 1.389 & 0.783 & 1207 & 1.345 & 1.957 & 0.911 & 1.288 \\
\hline Azerbaijan & 2.118 & 1.267 & 1.888 & 2.045 & 1.249 & 1.522 & 2.063 \\
\hline Belarus & 1.592 & 1.001 & 1.241 & 1.526 & 1.321 & 1.336 & 1.508 \\
\hline Bulgaria & 1.490 & 1.875 & 1.479 & 1.555 & 1.395 & 1.822 & 1.527 \\
\hline Croatia & 1.532 & 1.929 & 1.463 & 1.576 & 1.377 & 1.834 & 1.539 \\
\hline Czech Republic & 1.584 & 1.973 & 1.539 & 1.635 & 1.458 & 1.955 & 1.604 \\
\hline Estonia & 1.456 & 3.186 & 1.618 & 1.462 & 1.547 & 2.596 & 1.581 \\
\hline Hungary & 1.763 & 2.111 & 1.757 & 1.838 & 1.666 & 2.111 & 1.799 \\
\hline Kazakhstan & 1.866 & 1.144 & 1.574 & 1.745 & 1.693 & 1.455 & 1.769 \\
\hline Kyrgyzstan & 1.612 & 0.966 & 1.293 & 1.553 & 1.361 & 1.205 & 1.472 \\
\hline Latvia & 1.800 & 3.407 & 2.024 & 1.806 & 1.950 & 2.879 & 1.924 \\
\hline Lithuania & 1.744 & 3.492 & 1.900 & 1.751 & 1.832 & 2.890 & 1.873 \\
\hline Poland & 1.552 & 1.966 & 1.528 & 1.611 & 1.446 & 1.944 & 1.587 \\
\hline Romania & 1.574 & 1.858 & 1.556 & 1.621 & 1.493 & 1.866 & 1.596 \\
\hline Russia & 1.934 & 1.398 & 1.622 & 1.818 & 1.742 & 1.674 & 1.793 \\
\hline Slovak Republic & 1.605 & 1.966 & 1.568 & 1.662 & 1.484 & 1.944 & 1.625 \\
\hline Slovenia & 1.708 & 2.017 & 1.674 & 1.772 & 1.584 & 1.995 & 1.723 \\
\hline Ukraine & 1.476 & 0.725 & 1.118 & 1.405 & 1.199 & 1.065 & 1.382 \\
\hline Uzbekistan & 1.728 & 1.023 & 1.287 & 1.649 & 1.384 & 1.429 & 1.612 \\
\hline & 1.659 & 1.794 & 1.544 & 1.651 & 1.534 & 1.812 & 1.646 \\
\hline Average & 2.118 & 3.492 & 2.024 & 2.045 & 1.957 & 2.890 & 2.063 \\
\hline Highest & 1.389 & 0.725 & 1.118 & 1.345 & 1.199 & 0.911 & 1.288 \\
\hline Lowest & 0.183 & 0.837 & 0.245 & 0.168 & 0.221 & 0.550 & 0.191 \\
\hline Std. Dev. & & \multicolumn{7}{|c|}{} \\
\hline
\end{tabular}


The sign on the structural reform index $\left(\right.$ Reform $\left._{\mathrm{i}, \mathrm{t}}\right)$ is negative as the higher values of index indicate progress in reforms. The robustness of all other coefficients do not change substantially by substituting the labor ratio variable with the reform index in regressions (B.1) to (B.7). In both groups of estimates represented in Table 3a and Table 4a, respectively, Azerbaijan on average has either the highest or the lowest value of country-specific constants. If Azerbaijan is excluded from regression (B.7), then the standard deviation of country-specific constants decreases to 0.166 and the average over all constants reduces to 1.622 . Because of that improvement, regression (B.7) from Table 4 is run with common constant terms, and results greatly improve. These results are reproduced in equation (B.8) with standard errors in parentheses.

$$
\begin{aligned}
& \log \left(\mathrm{P}_{\mathrm{T}} / \mathrm{P}_{\mathrm{N}}\right)=1.53-1,26 \log \left(\mathrm{a}_{\mathrm{T}}-\mathrm{a}_{\mathrm{N}}\right)-1.07 \text { share }-0.65 \text { govreal }- \\
& \quad 0.23 \text { reform }+0.06 \text { reform*baldummy }+0.31 \text { reform*fsudummy. } \\
& \quad(0.10) \\
& \left.\mathrm{R}^{2} \text { (adj. }\right)=0.506 \\
& \mathrm{~N}=188
\end{aligned}
$$

All coefficients except multiplicative dummy on the Baltic countries are significant at a 5 percent level of confidence. A constant takes a value of 1.53, which is close to an average of individual country-specific constants in equation (B.7), excluding Azerbaijan. Also, all other coefficients seem not to differ significantly from the coefficients estimated in equation (B.7). The coefficient on the FSU dummy has a positive sign indicating that the structural reforms had on average less impact on determining real exchange rates in the FSU countries relative to other parts of the region. Although the difference could originate in a different econometric approach to estimate equation (B.8), the results may also cast some doubts on the construction of the labor ratio variable used to indicate the extent of reforms in transition economies. Namely, the ratio between labor employed in tradable and non-tradable sectors is built under the assumption that the number of workers employed in the agriculture sector remains the same during transition. However, that was not the case in FSU countries, where the share of workers employed in the agriculture sector even increased during transition, while it remained the same - or even slightly 
decreased - in the CEE and Baltic countries (EBRD Transition Reports 1998 and 1999). For that reason, the structural changes proxied by the labor ratio were stronger in FSU countries relative to structural changes measured by the structural reform index. Results from regression (B.8) seem to account for that slight mis-specification in constructing the structural parameter variable for FSU countries. Nonetheless, one can still draw a rather fair conclusion that reforms in the Baltic countries and the FSU did not affect real exchange rate determination in a substantially different manner than reforms in CEE countries.

The results presented in Table $3 \mathrm{a}$ and Table $4 \mathrm{a}$ are fully consistent with the view that structural reforms in transition economies contributed to the real appreciation trend observed in the region from the beginning of transition. Since all regressions are run in transition time, the results indicate that we can still expect further appreciation of the real exchange rate in those economies that started with transition later. Most FSU countries were still in the fourth or fifth year of the transition process in 1998 with respect to more advanced transition economies. While other factors started to play a more significant role in determining the real exchange rate in those economies at later stages of the transition process, it is expected that the real exchange rate in FSU countries will replicate the behavior of early starters. To see the development of different factors affecting the real exchange rate in the first five years ${ }^{10}$ of the transition time, the next section graphically presents results obtained from regression analysis.

\subsection{Accounting for Real Exchange Rate Level}

For each time period, summing the product of each right-hand side coefficient and the corresponding data for each variable, and then averaging either over all countries or over the different groups of countries will calculate the contribution of each group variable. The results from the basic regression (A.1) in Table 3a underlie Figures 6 to 10 and relate to the evolution of the real exchange rate in transition economies. Stacked columns represent the level of real exchange rate in each year. The portions of columns correspond to actual contributions that each variable had to the level of the real exchange rate in each year of the transition process. The sum of all portions of a column and country-specific constants add up to the fitted value for the real exchange rate level in the respective year. Nonetheless, it is the dynamics of the contribution of

${ }^{10}$ The first five years of transition were taken to be able to directly compare developments in the real exchange rate across different groups of countries. 
each set of variables that is interesting in explaining the determination of the real exchange rate in transition economies.

Figure 6 shows that on average, structural reforms contributed the most to the level of the real exchange rate in the first five years of the transition process. In the third year of transition, however, productivity differential between labor productivity in the tradable and non-tradable sectors, and private demand for non-tradables, respectively, began to dominate the real exchange rate. The government consumption played a minor role in the combination of factors believed to determine the level of the real exchange rate.

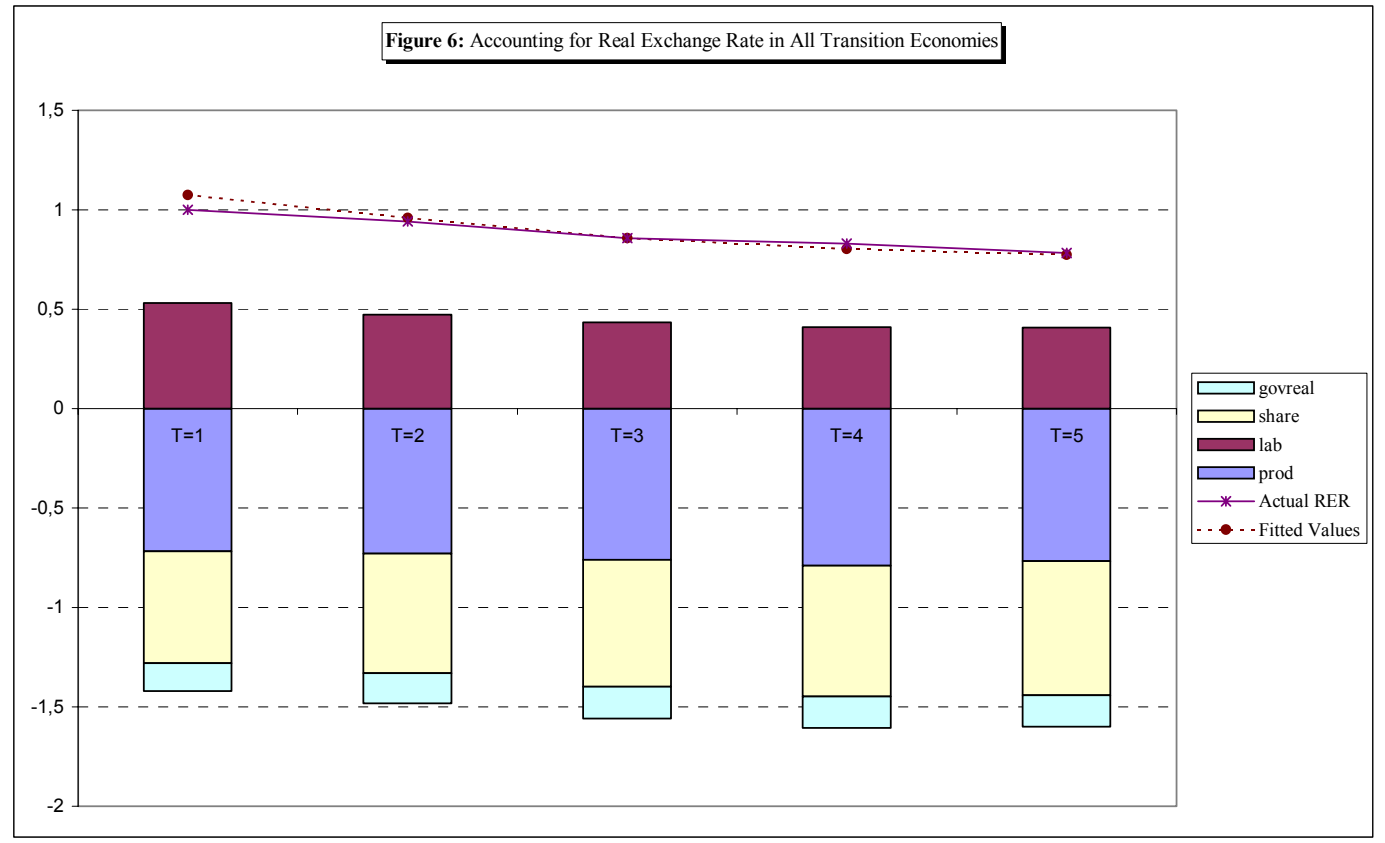

Sources: Table 3; and author's calculations.

Figure 6 could, however, lead to wrong conclusions as to which factors were the most important contributors to the real exchange rate determination in transition economies, since it only depicts averages for all transition economies. While the fifth year of transition represents the year 1998 for almost all FSU countries, CEE countries on average entered the eighth year of transition in 1998. Since year 1998 was crucial, especially for FSU countries because of the Russian financial crisis, wrong conclusions could be drawn from an analysis limited only to an average across all transition economies. Also, only Hungary and Poland entered the ninth year of 
transition; therefore, the last column represents the average only for Hungary and Poland. To grasp different dynamics of the transition process, Figures 7 to 9 present accounted levels of real exchange rates for CEE, the Baltics, and FSU, respectively.

To see clearer the Harrod-Balassa-Samuelson effect in the later stages of transition in CEE countries, Figure 7 presents the average contribution of different factors to the real exchange rate in CEE countries without Bulgaria and Romania. Those two countries have been less successful in implementing structural reforms and were exposed to political turmoil in 1997 and 1998. Also, only the first eight years of transition are shown in Figure 7 since in 1998, only Hungary and Poland were already in the ninth year of the transition process. Once the structural reforms were mainly accomplished - in the fifth year of transition for the most advanced transition economies on average - the productivity factors began to dominate real exchange rate appreciation.

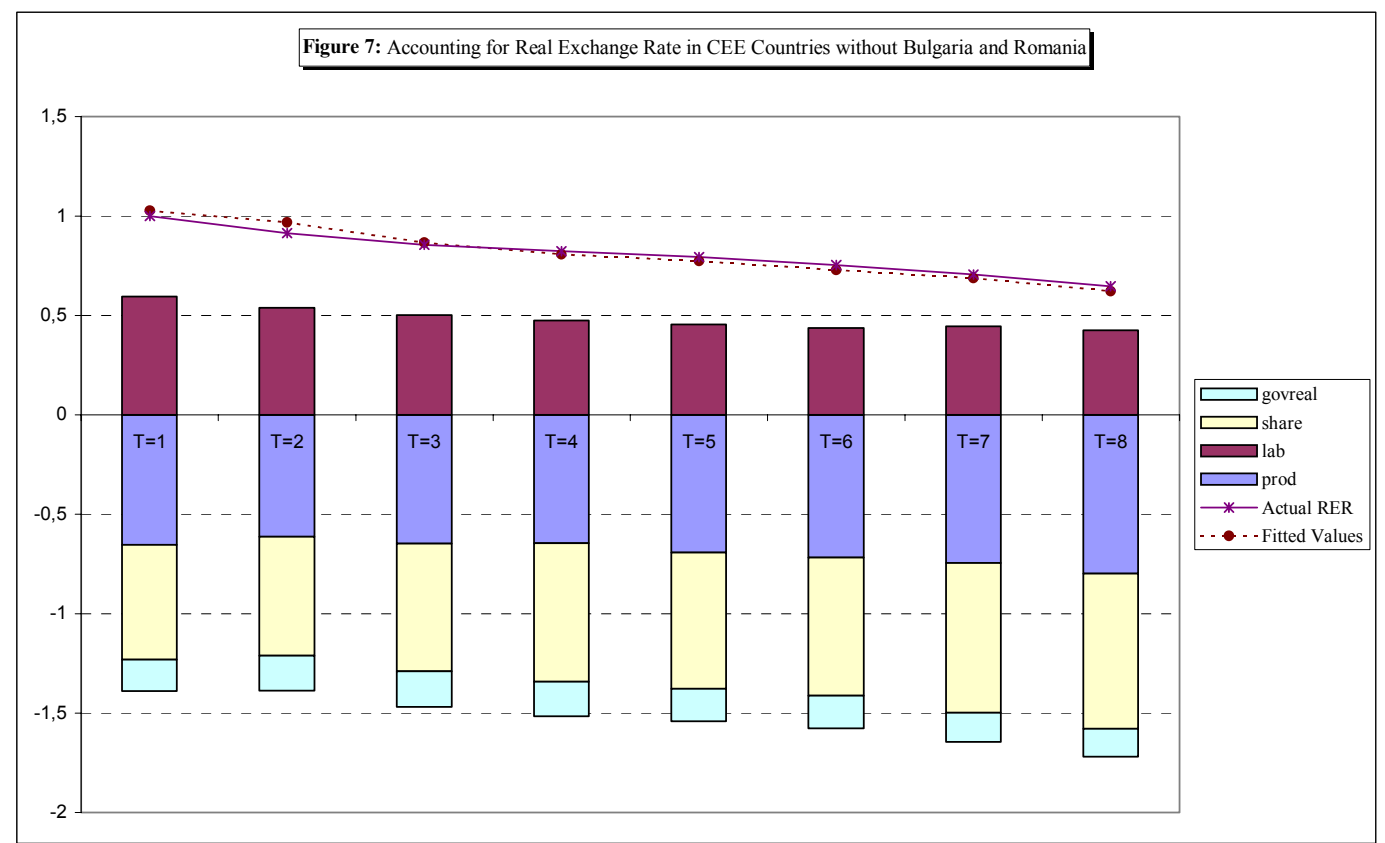

Sources: Table 3; and author's calculations. 
In the Baltic countries, the structural parameter development was similar to that of CEE countries. However, the demand factors, both private consumption of non-tradable goods and government consumption, respectively, had a more pronounced effect on the real exchange rate than in CEE countries. A dotted line in Figure 8 indicates the period in which only the average over Lithuania and Estonia is shown. In these two countries, demand factors significantly contributed to real exchange rate appreciation in the last years of the transition process, while productivity measure seemed to play a minor role in determining the real exchange rate throughout the whole transition period in the Baltic countries. In this respect, the Baltics were different from CEE countries, where it was shown that supply-side factors played a more important role in determining the real exchange rate - at least later in transition.

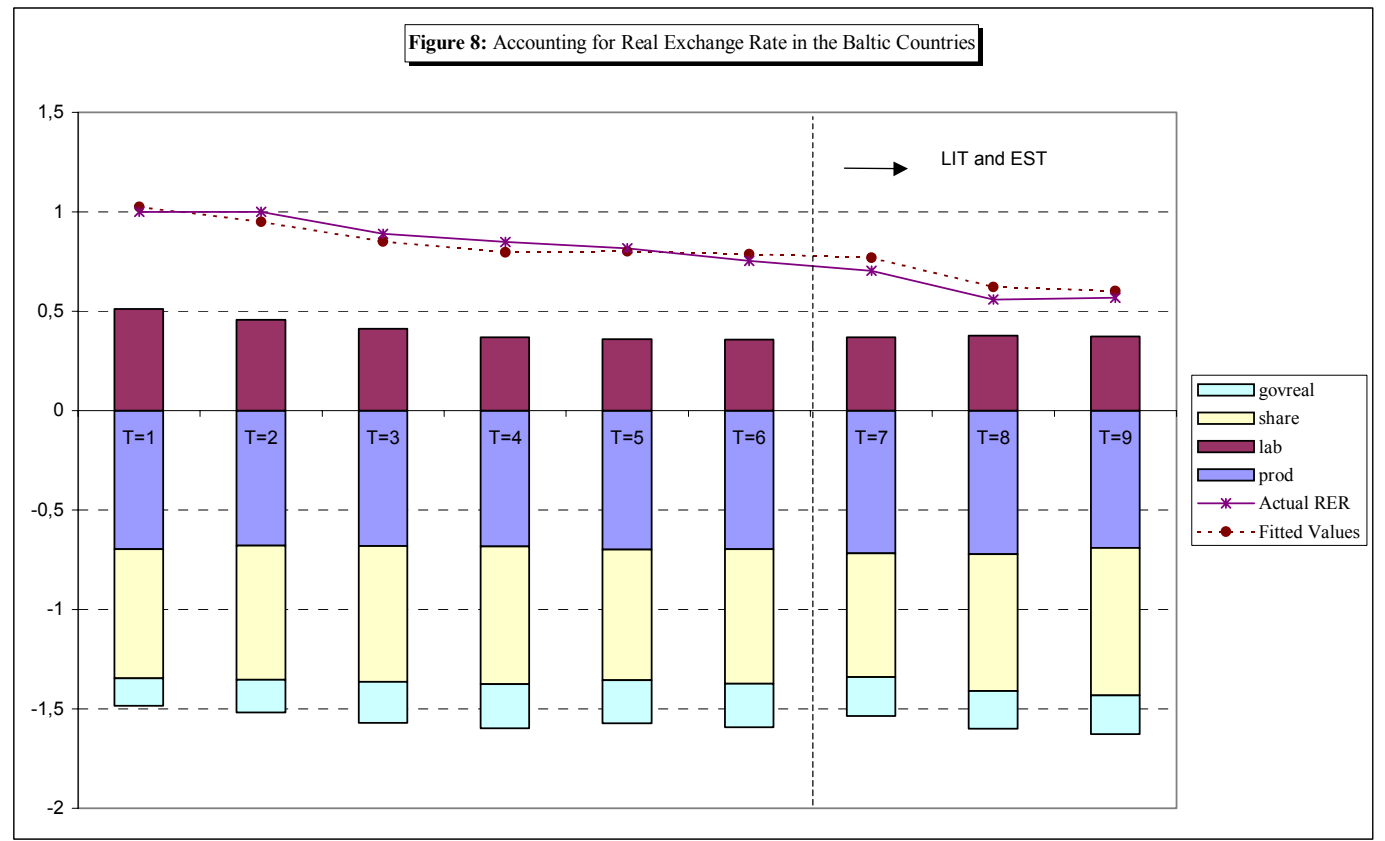

Sources: Table 3; and author's calculations.

Figure 9 presents the development of real exchange rate determinants in FSU countries. Differently than in the Baltics, structural reforms and productivity differential were the most significant contributors to real exchange rate appreciation during five years of transition experienced in FSU countries. However, the fifth year of transition in that region coincided with 
the Russian crisis; for that reason, one could say that the FSU would have still continued with structural reforms had the Russian crisis not prevented them from doing so. In contrast to other regions, structural reforms and productivity differential went almost hand in hand right from the beginning of transition in FSU countries, although it seems that development of the productivity differential was less intense than dynamics of structural reforms. The breakdown of this relationship occurred in the fifth year of transition when the Russian crisis took place. While the intensity of structural reforms remained almost the same, the productivity differential decreased rather substantially relative to the period prior to 1998. In addition, private demand for nontradables increased. Nonetheless, the correct story for the behavior of real exchange rate in FSU countries cannot be grounded only on such a short period of time; therefore, only speculations on the right factors determining real exchange rate in FSU countries could be cast.

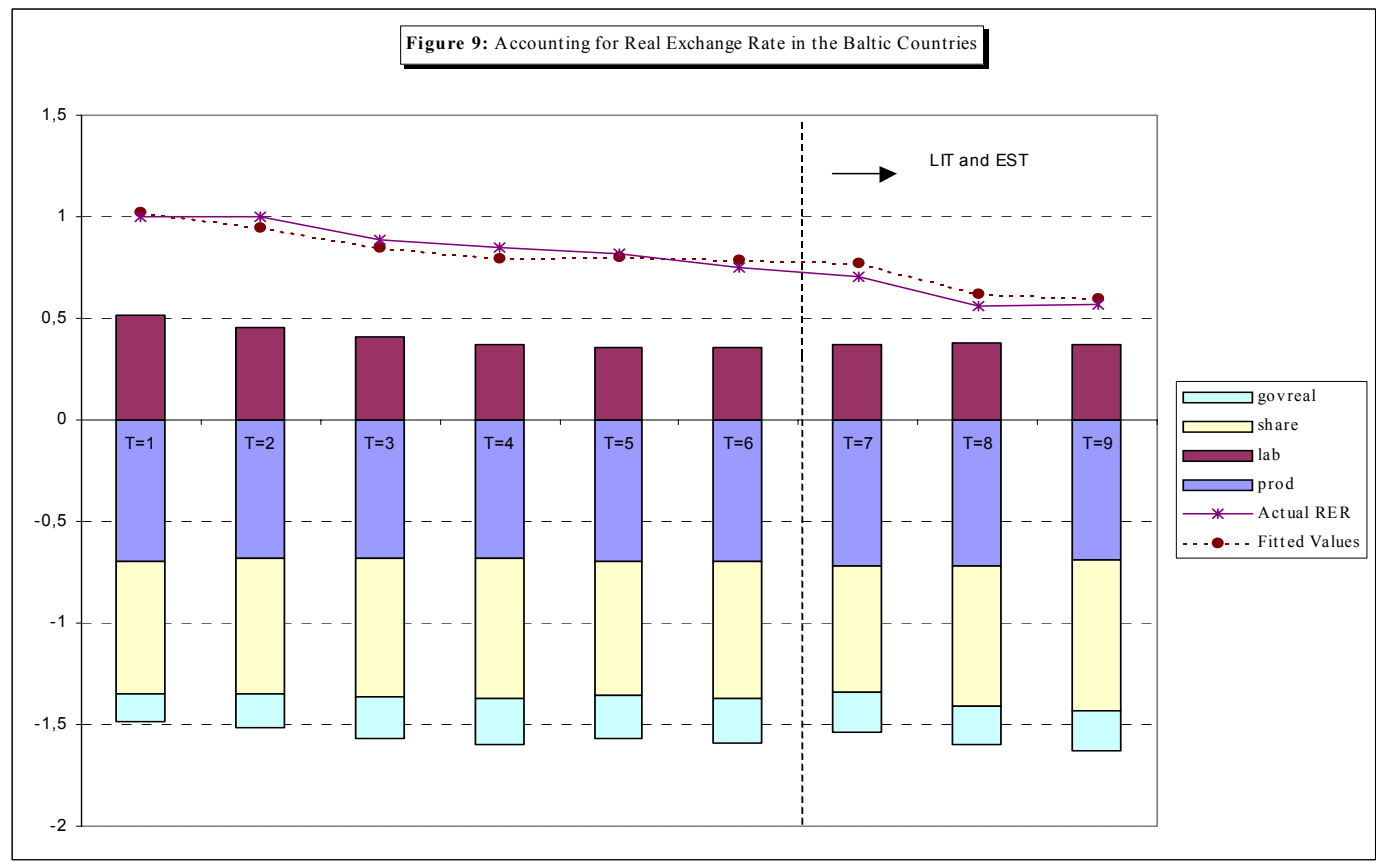

Sources: Table 3; and author's calculations.

On the one hand, part of the story for the real exchange rate determination in FSU countries can be attributed to more adverse initial conditions relative to other transition economies as is regularly acclaimed in growth models on. As transition took off in that region, structural reforms and productivity improvements in the tradable sector relative to the non- 
tradable sector improved almost simultaneously, accounting for worse macroeconomic and entrepreneurial conditions before transition relative to other parts of the region. However, on the other hand, failure to clearly account for the real exchange rate determination in FSU countries could be attributed to variable construction in estimating equation (33). As it was established earlier, the labor ratio in FSU countries may suffer from a mis-specification if an increase in the share of workers employed in the agriculture sector is not taken into account. Namely, if the ratio between workers employed in the tradable to non-tradable sector is corrected for by an increase in the share of workers employed in the agriculture sector, then structural reforms in FSU countries progressed less than indicated in Figure 9. For that reason, one could say that the main reason for the real exchange rate appreciation in FSU countries during the first five years of transition could be attributed to the Harrod-Balassa-Samuelson effect. Moreover, as structural reform indices in Table 5 show, the reforms are far from over in FSU countries relative to the values of the structural reform indices in CEE countries and the Baltics, respectively. The values of the structural reform index for each country are shown for the period of observation used in the estimation of equation (33).

Under the maintained assumption that the regression equations presented in Tables III.4 and III.5 are well-specified, it is expected that progress in structural reforms in FSU countries toward the extent of reforms in the CEE and Baltic countries will cause further real exchange rate appreciation in that region. In that respect, FSU countries are different from the CEE and Baltic countries, where structural reforms were more advanced and other factors began to dominate real exchange rate appreciation. 
William Davidson Institute Working Paper 482

Table 5: Structural Reform Indices in Transition Economies

\begin{tabular}{|l|l|l|l|l|l|l|l|l|l|}
\hline Country & 1990 & 1991 & 1992 & 1993 & 1994 & 1995 & 1996 & 1997 & 1998 \\
\hline
\end{tabular}

\begin{tabular}{|c|c|c|c|c|c|c|c|c|c|}
\hline CEE & & & & & & & & & \\
\hline Bulgaria & $\ldots$ & 0.62 & 0.86 & 0.66 & 0.63 & 0.61 & 0.57 & 0.67 & 0.67 \\
\hline Croatia & $\ldots$ & $\ldots$ & $\ldots$ & 0.79 & 0.79 & 0.71 & 0.75 & 0.74 & 0.74 \\
\hline Czech Republic & $\ldots$ & 0.79 & 0.86 & 0.90 & 0.88 & 0.82 & 0.82 & 0.82 & 0.82 \\
\hline Hungary & 0.57 & 0.74 & 0.78 & 0.82 & 0.83 & 0.82 & 0.82 & 0.87 & 0.88 \\
\hline Poland & 0.68 & 0.72 & 0.82 & 0.82 & 0.83 & 0.79 & 0.79 & 0.81 & 0.82 \\
\hline Romania & $\ldots$ & $\ldots$ & $\ldots$ & 0.58 & 0.67 & 0.65 & 0.64 & 0.66 & 0.65 \\
\hline Slovak Republic & $\ldots$ & 0.79 & 0.86 & 0.83 & 0.83 & 0.79 & 0.79 & 0.77 & 0.78 \\
\hline Slovenia & $\ldots$ & $\ldots$ & 0.78 & 0.82 & 0.79 & 0.79 & 0.79 & 0.79 & 0.79 \\
\hline
\end{tabular}

\begin{tabular}{|l|c|c|c|c|c|c|c|c|c|}
\hline \multicolumn{1}{|l|}{ Baltics } & \multicolumn{10}{|c|}{} \\
\cline { 1 - 9 } Estonia & 0.20 & 0.32 & 0.64 & 0.81 & 0.83 & 0.77 & 0.78 & 0.82 & 0.82 \\
\hline Latvia & $\ldots$ & $\ldots$ & $\ldots$ & 0.67 & 0.71 & 0.67 & 0.74 & 0.74 & 0.73 \\
\hline Lithuania & $\ldots$ & $\ldots$ & 0.55 & 0.78 & 0.79 & 0.71 & 0.74 & 0.74 & 0.74 \\
\hline
\end{tabular}

\begin{tabular}{|l|c|c|c|c|c|c|c|c|c|}
\hline \multicolumn{1}{|l|}{ FSU } & \multicolumn{10}{|c|}{} & $\ldots$ & $\ldots$ & $\ldots$ & $\ldots$ & 0.46 & 0.54 & 0.61 & 0.61 & 0.65 \\
\hline Armenia & $\ldots$ & $\ldots$ & $\ldots$ & $\ldots$ & $\ldots$ & 0.40 & 0.44 & 0.51 & 0.56 \\
\hline Azerbaijan & $\ldots$ & $\ldots$ & $\ldots$ & $\ldots$ & 0.42 & 0.50 & 0.44 & 0.37 & 0.34 \\
\hline Belarus & $\ldots$ & $\ldots$ & $\ldots$ & $\ldots$ & 0.42 & 0.50 & 0.64 & 0.66 & 0.68 \\
\hline Kazakhstan & $\ldots$ & $\ldots$ & $\ldots$ & 0.60 & 0.71 & 0.71 & 0.67 & 0.70 & 0.70 \\
\hline Kyrgyzstan & $\ldots$ & $\ldots$ & $\ldots$ & $\ldots$ & 0.67 & 0.64 & 0.71 & 0.72 & 0.61 \\
\hline Russia & $\ldots$ & $\ldots$ & $\ldots$ & $\ldots$ & 0.33 & 0.54 & 0.57 & 0.59 & 0.58 \\
\hline Ukraine & $\ldots$ & $\ldots$ & $\ldots$ & $\ldots$ & 0.50 & 0.57 & 0.57 & 0.54 & 0.51 \\
\hline Uzbekistan & $\ldots$ &
\end{tabular}

Sources: EBRD Transition Reports 1998 and 1999; and Havrylyshyn et al., (1999). 


\subsection{Initial Conditions and Dynamics of Structural Reforms}

To capture possible effects of adverse initial conditions on the real exchange rate behavior, apart from variables already included in estimating our model in Section 5.4., and to account for the progress in structural reforms, time and trend dummies were added to regression equation (B.1) from Table 4a. Also, the degrees of freedom increase since less dummy variables are used relative to regressions in Table $4 \mathrm{a}$. The time dummy takes value 1 in the corresponding year of the transition process, and zero otherwise. The trend dummy takes value 1 for the first year of the transition process; 2 for the second year; and correspondingly for each year of transition up to the ninth year for Estonia, Hungary, and Poland. For the reasons stated above, the structural reform index was used in estimating equation (B.1) instead of the labor ratio to capture the effect of reforms on the real exchange rate determination.

Regression (C.1) in Table 6 includes both time and trend dummies, respectively. Although only few are significant at a 5 percent level, joint F-test rejects the null hypothesis of all coefficients being equal to zero. The coefficients on independent variables are significant except the coefficient on government consumption, which was mostly insignificant already in regressions with country-specific dummies. Unfortunately, time and trend dummies do not show any significant development during the transition period. One would expect a diminishing effect of individual time dummy as much as a diminishing effect of reforms on the real exchange rate determination. However, when time and trend dummies are estimated separately, results greatly improve.

As can be seen from Table 6, regression (C.2) captures the diminishing effect of all unobserved effects accounted for by time dummies. The coefficients on time dummies are significant at a 5 percent level up to the fifth year of transition. The sixth year dummy variable is significant at a 10 percent level, while all other time dummies turn out to be insignificant. An economic explanation for this effect could be that adverse initial conditions 
Table 6: Regressions including Time-Varying Initial Conditions and Trend

\begin{tabular}{|l|l|l|l|l|l|l|}
\hline & \multicolumn{5}{|c|}{ Dependent Variable: $\log \left(P_{T} / P_{N}\right)_{I, t}$} \\
\hline Variable & \multicolumn{2}{|c|}{$(\mathrm{C} .1)$} & \multicolumn{2}{c|}{$(\mathrm{C} .2)$} & \multicolumn{2}{c|}{$(\mathrm{C} .3)$} \\
\hline Constant & $0.849^{* *}$ & $(0.253)$ & $0.644^{* *}$ & $(0.241)$ & $0.868^{* *}$ & $(0.195)$ \\
\hline $\log \left(\mathrm{a}_{\mathrm{T}}-\mathrm{a}_{\mathrm{N}}\right)_{\mathrm{i}, \mathrm{t}}$ & $-0.549^{* *}$ & $(0.147)$ & $-0.539^{* *}$ & $(0.149)$ & $-0.546^{* *}$ & $(0.151)$ \\
\hline Share $_{\mathrm{i}, \mathrm{t}}$ & $-0.673^{* *}$ & $(0.154)$ & $-0.716^{* *}$ & $(0.149)$ & $-0.695^{* *}$ & $(0.149)$ \\
\hline Govreal $_{\mathrm{i}, \mathrm{t}}$ & -0.142 & $(0.250)$ & -0.134 & $(0.241)$ & -0.129 & $(0.241)$ \\
\hline Reform $_{\mathrm{i}, \mathrm{t}}$ & & & $-0.353^{* *}$ & $(0.119)$ & & \\
\hline
\end{tabular}

\begin{tabular}{|c|l|l|l|l|l|l|}
\hline Time1 & -0.042 & $(0.199)$ & $0.271^{* *}$ & $(0.062)$ & & \\
\hline Time2 & 0.042 & $(0.318)$ & $0.255^{* *}$ & $(0.069)$ & & \\
\hline Time3 & 0.167 & $(0.359)$ & $0.199^{* *}$ & $(0.072)$ & & \\
\hline Time4 & $0.198^{* *}$ & $(0.080)$ & $0.201 * *$ & $(0.078)$ & & \\
\hline Time5 & 0.112 & $(0.311)$ & $0.173^{* *}$ & $(0.659)$ & & \\
\hline Time6 & -0.445 & $(0.646)$ & $0.108^{*}$ & $(0.064)$ & & \\
\hline Time7 & $-1.059 * *$ & $(0.447)$ & 0.046 & $(0.069)$ & & \\
\hline Time8 & $-1.584^{* *}$ & $(0.329)$ & -0.028 & $(0.082)$ & & \\
\hline Time9 & $-3.629 * *$ & $(0.341)$ & -0.068 & $(0.083)$ & & \\
\hline
\end{tabular}

\begin{tabular}{|l|l|l|l|l|l|l|}
\hline Reform*Trend1 & -0.172 & $(0.114)$ & & & $-0.268^{* *}$ & $(0.122)$ \\
\hline Reform*Trend2 & -0.175 & $(0.156)$ & & & $-0.157^{* *}$ & $(0.057)$ \\
\hline Reform*Trend3 & $-0.205^{*}$ & $(0.117)$ & & & $-0.133^{* *}$ & $(0.039)$ \\
\hline Reform*Trend4 & $-0.164 * *$ & $(0.072)$ & & & $-0.104^{* *}$ & $(0.029)$ \\
\hline Reform*Trend5 & $-0.114 *$ & $(0.062)$ & & & $-0.087 * *$ & $(0.023)$ \\
\hline Reform*Trend6 & 0.0175 & $(0.134)$ & & & $-0.085^{* *}$ & $(0.018)$ \\
\hline Reform*Trend7 & 0.114 & $(0.074)$ & & & $-0.084^{* *}$ & $(0.017)$ \\
\hline Reform*Trend8 & $0.167 * *$ & $(0.046)$ & & & $-0.083^{* *}$ & $(0.017)$ \\
\hline Reform*Trend9 & $0.403 * *$ & $(0.038)$ & & & $-0.078^{* *}$ & $(0.015)$ \\
\hline
\end{tabular}

\begin{tabular}{|c|c|c|c|}
\hline Adj. $\mathrm{R}^{2}$ & 0.564 & 0.563 & 0.557 \\
\hline $\mathrm{N}$ & 122 & 122 & 122 \\
\hline
\end{tabular}

Note: Numbers in parentheses are t-ratios based on heteroscedasticity-adjusted standard errors. The $* *$ indicate that the coefficient is significantly greater or smaller than zero, as appropriate, at a 5 percent level; The * indicates significance at a 10 percent level. 
were slowly dying out as transition progressed, and as such, contributed to real exchange rate appreciation. The coefficient on productivity differential is slightly smaller than in regression (B.1) in Table 4a, while the coefficient on structural reforms remained the same. The coefficient on government consumption became insignificant, whereas the effect of private demand for nontradables substantially decreased relative to the value obtained in regression (B.1) in Table 4a. It could be argued that most of the effect of adverse initial conditions on real exchange rate appreciation was incorporated in private consumption of non-tradables in regression (B.1) in Table 4a. A possible explanation for this effect may be nested in a significant monetary overhang observed in all transition economies at the beginning of transition. For that reason, the timevarying initial conditions - captured by time dummies - diminished the effect of private demand for non-tradables on real exchange rate determination.

Regression (C.3) in Table 6 adds a multiplicative trend dummy to the basic regression (B.1) from Table 4a. The value 1 is assigned to the trend dummy in the first year of transition, and zero in all other periods. Correspondingly, the dummy takes value 9 in the last year of the transition process, and zero otherwise. The trend dummy is interacted with the structural reform index to capture the dynamics of structural reforms in the real exchange rate determination. The coefficients on basic variables remained almost the same as in regression (C.2). All were significant at a 5 percent level, except the coefficient on government consumption. Additionally, all interaction terms were significant indicating the importance of structural reforms in determining the real exchange rate. However, the coefficients were slowly diminishing from 0.268 in the first year of transition to -0.875 in the fifth year of the transition process. From then on, they remained almost constant up to the ninth year of transition, which is represented only by Estonia, Hungary, and Poland. Since those countries were the most advanced reformers, they accomplished reforms earlier, as is shown in Table 5. The smaller values of interaction terms from the fifth year of transition on indicate that for most transition economies, the effect of structural reforms on the real exchange rate appreciation diminished and other factors began to dominate the real exchange rate. The results from regression (C.3), therefore, confirm the graphical exposition for exchange rate accounting in Section 5.1. If all regressions in Table 6 are run only for the first five years of transition - where all countries, except Azerbaijan, were in transition for the whole period - results do not change substantially, indicating that structural reforms indeed contributed to the real exchange rate appreciation only in the first five years of transition. After that, other factors began to dominate the real exchange rate appreciation trend. 


\section{Conclusions}

This paper has attempted to develop a model suitable for the analysis of the real exchange rate appreciation in transition economies. The structural models of the real exchange rate seem to be the most appropriate approach employed to analyze the commonly observed real appreciation trend in the transition economies. For that reason, the model of De Gregorio, Giovannini, and Krueger (1993) was extended in order to introduce a variable representing the structural reform progress in transition. Similar to growth models of transition (Berg et al., 1999; Havrylyshyn, Izvorski, and van Rooden, 1998), it was shown that adverse initial conditions and structural reforms affected the real exchange rate measured as the relative price of tradables in terms of non-tradable goods only in the first five years of the transition process. After that period, other factors began to dominate the real exchange rate determination. All countries entered the sample in the year when the most serious stabilization attempt was introduced. In so doing, it was possible to distinguish the extent of the reforms implemented in each group of transition countries and their impact on the real exchange rate determination.

Since only advanced transition economies are engaged in transition for more than five years, speculations are cast for further developments in the real exchange rate in less advanced transition economies. It is argued that they will observe trend appreciation determined by structural reforms at least as long as they catch up with more advanced economies. While the CEE countries have experienced an increase in productivity differential between labor productivity in the tradable and non-tradable sector at the later stages of transition, the demand factors seemed to play a more pronounced role in determining real exchange rate in the Baltic countries. Although an explicit analysis of the external competitiveness in the theoretical framework employed in this paper is not possible, one could argue that an increased effect of demand factors on the real exchange rate in the Baltic countries at later stages of transition caused a loss in external competitiveness reflected in a current account deficit, which is on average higher than in more advanced CEE countries.

One could argue that the analysis of the real exchange rate in transition economies should also account for a surge in capital flows observed from the beginning of transition and different exchange rate regimes maintained by monetary authorities in transition economies. Again, an explicit analysis is not possible. However, exchange rate regimes seemed not to play any direct role in explaining output performance in different transition economies. The fixed exchange rate 
regime was used mainly to better contain the inflationary pressure, and as such, it affected the real output growth only indirectly through better inflation performance. However, it seems that the fixed exchange rate regime indeed affected the real exchange rate negatively in the case of the Baltic countries (they introduced a currency board as the most extreme fixed exchange rate regime). The link between the fixed exchange rate regime and the real exchange rate appreciation measured by a decrease in the relative price of tradables and non-tradables seems to be established through an increase in capital flows if they mainly increase domestic consumption rather than investment. Measured in cumulative per capita terms in the period 1991-97, foreign capital flows were indeed among the biggest in Estonia and Latvia (Jazbec, 1999). For that reason, it could be that only Bulgaria, Estonia, Latvia, and Lithuania were the only countries in 1998 still maintaining the fixed exchange rate regime (Fisher and Sahay, 2000).

Although the role of initial conditions on the real exchange rate determination was not explicitly studied, time dummies were employed in regression analysis to account for unobservable factors at different stages of the transition process. The main results were robust to that manipulation. Moreover, the coefficients on time-specific effects slowly diminished to the sixth year of the transition process confirming the story that for the most transition economies, structural reforms did not affect the real exchange rate determination at later stages of transition. Under the maintained assumption that the theoretical framework and regression equations are well-specified, one could tentatively conclude that for the more advanced transition economies, the transition process is over in a sense that adverse initial conditions and structural reforms no longer contribute to the real exchange rate appreciation. For that reason, the conclusion of Halpern and Wyplosz (1996) is challenged in a way that transition is not over when real appreciation ends, but when the effect of structural reforms on the real exchange rate is significantly diminished relative to other factors determining the real exchange rate. 


\section{REFERENCES}

Aghevli, Bijan B., Mohsin S. Khan, and Peter J. Montiel, "Exchange Rate Policy in Developing Countries: Some Analytical Issues”, IMF Occasional Paper, No. 78, March 1991.

Aizenman, Joshua, and Peter Isard, "The Sustainability of Economic Transformation", The Journal of Policy Reform, Vol. 1, 1996, pp. 413-440.

Aslund, Anders, Peter Boone, and Simon Johnson, "How to Stabilize: Lessons from Postcommunist Countries", Brookings Papers on Economic Activity, No. 1, Washington, 1996.

Balassa, Bela, "The Purchasing Power Parity Doctrine: A Reappraisal", Journal of Political Economy, Vol. 72, December 1964, pp. 584-596.

Berg, Andrew, Eduardo Borensztein, Ratna Sahay, and Jeromin Zettelmeyer, "The Evolution of Output in Transition Economies: Explaining the Differences", IMF Working Paper, No. 73, May 1999.

Bhagwati, Jagdish N., "Why are Services Cheaper in the Poor Countries?", The Economic Journal, Vol. 94, No. 374, June 1984, pp. 279-287.

Brada, Josef C., "Introduction: Exchange Rates, Capital Flows, and Commercial Policies in Transition Economies", Journal of Comparative Economics, 26, 1998, pp. 613 -620.

Coorey, Sharmini, Mauro Mecagni, and Erik Offerdal, "Disinflation in Transition Economies: The Role of Relative Price Adjustment", IMF Working Paper, No. 138, December 1996.

De Gregorio, Jose, Alberto Giovannini, and Thomas H. Krueger, "The Behavior of Nontradable Goods Prices in Europe: Evidence and Interpretation”, IMF Working Paper, No. 45, May 1993.

De Melo, Martha, Alan Gelb, and Cevdet Denizer, "From Plan to Market: Patterns of Transition", Policy Research Working Paper 1564, World Bank, 1996.

Drabek, Zdenek, and Josef C. Brada, "Exchange Rate Regimes and the Stability of Trade Policy in Transition Economies", Journal of Comparative Economics, Vol. 26, 1998, pp. 642-668.

Edwards, Sebastian, "Real Exchange Rates in the Developing Countries: Concepts and Measurement”, NBER Working Paper, No. 2950, 1989.

Edwards, Sebastian, "Real and Monetary Determinants of Real Exchange Rate Behavior: Theory and Evidence from Developing Countries", in John Williamson, ed., Estimating Equilibrium Exchange Rates, Washington, D.C., Institute for International Economics, 1994. 
Fisher, Stanley, and Ratna Sahay, "The Transition Economies After Ten Years", IMF Working Paper, No. 30, 2000.

Fisher, Stanley, Ratna Sahay, and Carlos A. Vegh, "Stabilization and Growth in Transition Economies: The Early Experience", Journal of Economic Perspectives, Vol. 10, No. 2, Spring 1996, pp. 45-66.

Halpern, Laszlo, and Charles Wyplosz, "Equilibrium Exchange Rates in Transition Economies", IMF Working Paper, No. 125, 1996.

Havrylyshyn, Oleh, Ivailo Izvorski, and Ron van Rooden, "Recovery and Growth in Transition Economies 1990-97: A Stylized Regression Analysis", IMF Working Paper, No. 141, September 1998.

Havrylyshyn, Oleh, Thomas Wolf, Julian Berengaut, Marta Castello-Branco, Ron van Rooden, and Valerie Mercer-Blackman, "Growth Experience in Transition Countries, 90-98", IMF Occasional Paper, No. 184, April 2000.

Hinkle, Lawrence E., and Peter J. Montiel (ed.), Exchange Rate Misalignment: Concepts and Measurement for Developing Countries, Oxford University Press, 1999.

Jazbec, Bostjan, "Macroeconomic Stabilization and Capital Inflows in Transition Economies", Faculty of Economics Working Paper, No. 89, Ljubljana, September 1999.

Krajnyak, Kornelia, and Jeromin Zettelmeyer, "Competitiveness in Transition Economies: What Scope for Real Appreciation?” IMF Staff Papers, Vol. 45, No. 2, June 1998.

Melitz, Jacques, and Claire Waysand, "The Role of Government Aid to Firms during the Transition to a Market Economy: Russia 1992-1994", The Journal of Policy Reform, Vol. 1, 1996, pp. 299-334.

Richards, Anthony J., and Gunnar H. R. Tersman, "Growth, Nontradables, and Price Convergence in the Baltics", Journal of Comparative Economics, Vol. 23, 1996, pp. 121-145.

Samuelson, Paul A., "Theoretical Notes on Trade Problems", Review of Economics and Statistics, Vol. 46, March 1964, pp. 145-154.

Taube, Günther, and Jeromin Zettelmeyer, "Output Decline and Recovery in Uzbekistan: Past Performance and Future Prospects”, IMF Working Paper, No. 132, September 1998. 


\section{DAVIDSON INSTITUTE WORKING PAPER SERIES - Most Recent Papers}

The entire Working Paper Series may be downloaded free of charge at: www.wdi.bus.umich.edu

CURRENT AS OF 7/10/02

\begin{tabular}{|c|c|c|}
\hline Publication & Authors & Date \\
\hline No. 482: Real Exchange Rates in Transition Economies & Boštjan Jazbec & July 2002 \\
\hline $\begin{array}{l}\text { No. 481: Labor Force Participation Dynamics in the Romanian Labor } \\
\text { Market }\end{array}$ & Alexandru Voicu & July 2002 \\
\hline $\begin{array}{l}\text { No. 480: Structural Change, Mismatch, and Job Mobility: Evidence } \\
\text { from Russia }\end{array}$ & $\begin{array}{l}\text { John S. Earle and Klara Z. } \\
\text { Sabirianova }\end{array}$ & Dec. 2001 \\
\hline $\begin{array}{l}\text { No. 479: The Impact of Minimum Wages on Wage Inequality and } \\
\text { Employment in the Formal and Informal Sector in Costa Rica }\end{array}$ & $\begin{array}{l}\text { Fatma El-Hamidi and Katherine } \\
\text { Terrell }\end{array}$ & Apr. 2001 \\
\hline $\begin{array}{l}\text { No. 478: Beyond Oaxaca -Blinder: Accounting for Differences in } \\
\text { Household Income Distributions }\end{array}$ & $\begin{array}{l}\text { François Bourguignon, Francisco } \\
\text { H. G. Ferreira and Phillippe G. } \\
\text { Leite }\end{array}$ & Feb. 2002 \\
\hline $\begin{array}{l}\text { No. 477: Participation Behavior of East German Women after German } \\
\text { Unification }\end{array}$ & Holger Bonin and Rob Euwals & July 2002 \\
\hline No. 476: Duration and Risk of Unemployment in Argentina & $\begin{array}{l}\text { Sebastian Galiani and Hugo A. } \\
\text { Hopenhayn }\end{array}$ & Oct. 2001 \\
\hline $\begin{array}{l}\text { No. 475: After, Before and During: Returns to Education in the } \\
\text { Hungarian Transition }\end{array}$ & $\begin{array}{l}\text { Nauro F. Campos and Dean } \\
\text { Jolliffe }\end{array}$ & Apr. 2002 \\
\hline No. 474: The Locking-in Effect of Subsidized Jobs & Jan C. van Ours & June 2002 \\
\hline No. 473: How Reform Worked in China & Yingyi Qian & June 2002 \\
\hline No. 472: An Economic Perspective on Russia's Accession to the WTO & Robert M. Stern & June2002 \\
\hline $\begin{array}{l}\text { No. 471: The Effects of Ownership Forms and Concentration on Firm } \\
\text { Performance after Large-Scale Privatization }\end{array}$ & Evzen Kocenda and Jan Svejnar & May 2002 \\
\hline $\begin{array}{l}\text { No. 470: Growth in Transition: What We Know, What We Don't, and } \\
\text { What We Should }\end{array}$ & $\begin{array}{l}\text { Nauro F. Campos and Fabrizio } \\
\text { Coricelli }\end{array}$ & Feb. 2002 \\
\hline $\begin{array}{l}\text { No. 469: Barriers to Investment by Russian Firms: Property Protection } \\
\text { or Credit Constraints? }\end{array}$ & Susan J. Linz & May 2002 \\
\hline No. 468: Job Satisfaction Among Russian Workers & Susan J. Linz & May 2002 \\
\hline $\begin{array}{l}\text { No. 467: Assessing the Problem of Human Capital Mismatch in } \\
\text { Transition Economies }\end{array}$ & $\begin{array}{l}\text { Viliam Druska, Byeong ju Jeong, } \\
\text { Michal Kejak, and Viatcheslav } \\
\text { Vinogradov }\end{array}$ & Mar. 2002 \\
\hline $\begin{array}{l}\text { No. 466: Motivating Russian Workers: Analysis of Age and Gender } \\
\text { Differences }\end{array}$ & Susan J. Linz & Feb. 2002 \\
\hline No. 465: Virtual Reality: Barter and Restructuring in Russian Industry & Gary Krueger and Susan J. Linz & Apr. 2001 \\
\hline $\begin{array}{l}\text { No. 464: Lending of Last Resort, Moral Hazard and Twin Crises: } \\
\text { Lessons from the Bulgarian Financial Crisis 1996/1997 }\end{array}$ & $\begin{array}{l}\text { Michael Berlemann, Kalin } \\
\text { Hristov and Nikolay Nenovsky }\end{array}$ & May 2002 \\
\hline $\begin{array}{l}\text { No. 463: Deindustrialisation. Lessons from the Structural Outcomes of } \\
\text { Post-Communist Transition }\end{array}$ & $\begin{array}{l}\text { Tomasz Mickiewicz and Anna } \\
\text { Zalewska }\end{array}$ & Jan. 2002 \\
\hline $\begin{array}{l}\text { No. 462: Joint Liability Lending and the Rise and Fall of China's } \\
\text { Township and Village Enterprises }\end{array}$ & Albert Park and Minggao Shen & July 2001 \\
\hline $\begin{array}{l}\text { No. 461: A Refinancing Model of Decentralization with Empirical } \\
\text { Evidence from China }\end{array}$ & Albert Park and Minggao Shen & Apr. 2002 \\
\hline $\begin{array}{l}\text { No. 460: The Effects of Market Liberalization on the Relative Earnings } \\
\text { of Chinese Women }\end{array}$ & $\begin{array}{l}\text { Margaret Maurer-Fazio and } \\
\text { James Hughes }\end{array}$ & Mar. 2002 \\
\hline $\begin{array}{l}\text { No. 459: The Role of Education in Determining Labor Market } \\
\text { Outcomes in Urban China's Transitional Labor Markets }\end{array}$ & Margaret Maurer-Fazio & Apr. 2002 \\
\hline $\begin{array}{l}\text { No. 458: Real and Monetary Convergence within the European Union } \\
\text { and Between the European Union and Candidate Countries: } \\
\text { A Rolling Cointegration Approach }\end{array}$ & $\begin{array}{l}\text { Josef C. Brada, Ali M. Kutan and } \\
\text { Su Zhou }\end{array}$ & Apr. 2002 \\
\hline No. 457: Credit Ratings as Coordination Mechanisms & $\begin{array}{l}\text { Arnoud W. A. Boot and Todd T. } \\
\text { Milbourn }\end{array}$ & Mar. 2002 \\
\hline
\end{tabular}

